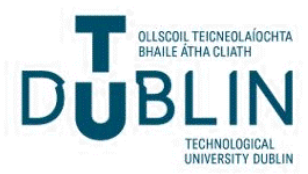

Technological University Dublin

ARROW@TU Dublin

2003-01-01

\section{Indirect Evaporative Cooling Potential in Air-water Systems in Temperate Climates}

\author{
Ben Costelloe \\ Technological University Dublin, ben.costelloe@tudublin.ie \\ Donal Finn \\ University College Dublin, donal.finn@tudublin.ie
}

Follow this and additional works at: https://arrow.tudublin.ie/engschcivart

Part of the Energy Systems Commons, Environmental Design Commons, Other Civil and

Environmental Engineering Commons, Science and Mathematics Education Commons, Technology and Innovation Commons, and the Thermodynamics Commons

\section{Recommended Citation}

Costelloe, B., Finn, D.: Indirect Evaporative Cooling Potential in Air-Water Systems in Temperate Climates. Energy and Buildings 35 (2003) 573-591. doi:10.1016/S0378-7788(02)00161-5

This Article is brought to you for free and open access by the School of Civil and Structural Engineering at ARROW@TU Dublin. It has been accepted for inclusion in Articles by an authorized administrator of ARROW@TU

Dublin. For more information, please contact

arrow.admin@tudublin.ie, aisling.coyne@tudublin.ie, gerard.connolly@tudublin.ie.

Funder: CIBSE, Enterprise Ireland, DIT Seed Fund

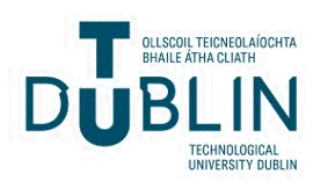




\title{
Indirect evaporative cooling potential in air-water systems in temperate climates
}

\author{
B. Costelloe ${ }^{\mathrm{a}, *}$, D. Finn ${ }^{\mathrm{b}}$ \\ ${ }^{a}$ Department of Building Services Engineering, Dublin Institute of Technology, Dublin, Ireland \\ ${ }^{\mathrm{b}}$ Department of Mechanical Engineering, University College Dublin, Dublin, Ireland
}

Received 30 June 2002; received in revised form 21 August 2002; accepted 25 August 2002

\begin{abstract}
Recent developments have prompted a review of evaporative cooling technology as an effective means of cooling modern deep plan buildings. Prominent among these developments is the success of high temperature sensible cooling systems, particularly, chilled ceilings, which require a supply of cooling water at $14-18{ }^{\circ} \mathrm{C}$. Crucial to the success of evaporative cooling technology, as a significant means of cooling in modern applications, is the ability to generate cooling water, in an indirect circuit, at a temperature which closely approaches the ambient adiabatic saturation temperature (AST) or wet bulb temperature (WBT). Recent experimental research has demonstrated that it is technically viable to generate such cooling water at a temperature of $3 \mathrm{~K}$ above the ambient AST.

While the frequency of ambient AST occurrence can be obtained from meteorological sources, there is little in-depth analysis of the potential for this form of cooling water generation, based on the approach temperatures which have now been shown to be viable. The decision to use an evaporative cooling system depends largely on an assessment, in-depth, of net energy saved against capital expended. Such an assessment requires detailed data on the availability of cooling water, generated by evaporation, for each location. This paper quantifies evaporative cooling availability in-depth for a northern and southern European city, Dublin and Milan and suggests a method of analysing such data for any world wide location, for which suitable meteorological records are available. The paper, incorporates recent experimental research findings and bases the availability analysis on meteorological test reference weather year data.

The results of this research confirm a major potential for the generation of cooling water by evaporative means, which can be used to provide effective cooling of deep plan buildings by means of contemporary water based sensible cooling systems, such as fan coil systems, radiant chilled ceiling panels and ceiling cooling convectors (chilled beams). While the technique offers most potential in locations with a northern European temperate climate, it has significant potential to contribute to cooling in some southern European cities, during the nonsummer months and also at other times, particularly where load shaving techniques are incorporated.
\end{abstract}

(C) 2002 Elsevier Science B.V. All rights reserved.

Keywords: Free cooling; Low energy cooling; Evaporative cooling; Cooling towers; Chilled ceilings; Chilled ceiling panels; Chilled beams

\section{Introduction}

Buildings, which have significant latent loads and which require high rates of air supply for ventilation purposes are often treated with all-air, air conditioning systems, in which all conditioning equipment is confined to a central location and from which the treated air supply to the building is distributed. Such systems combine the latent and sensible cooling functions in the central plant cooling coils and require chilled water at low temperatures, typically $5-8{ }^{\circ} \mathrm{C}$, to produce dehumidification on the coils. These systems generally rely on vapour compression refrigeration to generate the required chilled water temperatures.

\footnotetext{
${ }^{*}$ Corresponding author. Tel.: +353-1-4023826; fax: +353-1-4926326. E-mail address: ben.costelloe@dit.ie (B. Costelloe).
}

Not all buildings, however, need high rates of air supply for ventilation purposes or have significant latent loads or require close control of humidity. Such buildings are often successfully treated with air-water systems in which a smaller central air system (the primary air) is used to supply ventilation air and offset latent gains. A cooling water distribution system is also used (the secondary water) to supply local sensible cooling equipment in each zone. Such air-water systems are often applied in the perimeter zones of buildings which have significant external sensible loads. However, the system is also applied in interior zones to offset internally generated cooling loads. These systems work well in buildings such as offices and hotels $[3,17]$.

Air-water systems include the perimeter induction system, the dry mode fan coil system (fan coils which do not dehumidify the air) and the modern chilled ceiling, either in 
the form of the radiant panel or the active or passive chilled beam system (cooling convector placed at ceiling level). These systems require two supplies of chilled water; one at the conventional temperatures of $5-8{ }^{\circ} \mathrm{C}$ for primary air sensible and latent cooling and a second supply at a higher temperature, typically $11-18{ }^{\circ} \mathrm{C}$, for local sensible cooling. At present, these systems generally use conventional vapour compression refrigeration to generate all cooling water at temperatures suitable for primary air dehumidification and subsequently raise the water temperature to the required secondary temperature by means of a mixing arrangement or a heat exchanger. In the case of chilled ceiling panels, the return from the primary air chilled water loop can be used as the supply to the secondary water loop (by arranging the secondary cooling water in series with the primary cooling water) [3]. While water side evaporative cooling arrangements are occasionally used, with air-water systems, particularly in more arid climates, the use of the technique falls far short of its potential. This is particularly the case in west European temperate climates where many opportunities to benefit from evaporative cooling techniques are often overlooked [11]. This situation is attributed by Field [13] to a lack of in-depth knowledge of the energy performance of water side free cooling systems, in terms of the cooling generated per unit of primary energy expended. The decision to use an evaporative cooling system depends largely on an assessment, in-depth, of net energy saved against capital expended. Such an assessment requires detailed data on the availability of cooling water, generated by evaporation, for each location

This paper quantifies cooling availability for a northern and southern European city, Dublin and Milan, and suggests a method of analysing such data for any location for which suitable meteorological records are available. Dublin is at the lower end and Milan is at the upper end of the range of European locations shown in Table 1. Hence, most locations with a north-west European temperate climate would be likely to return an evaporative cooling performance between these two limits. The paper also addresses such issues as the variation in availability with the design secondary approach to wet bulb temperature (WBT) and with the time of year and time and length of the cooling day. Other issues addressed include an analysis of the unavailable times and an assessment of the penalty imposed by the indirect system, over the direct approach, in terms of the diminished cooling availability, which results. This work enables an extensive assessment of the evaporative cooling potential to be undertaken and hence the economic viability of the technique can be accurately quantified.

Ideally, in air-water systems, the secondary cooling coil is always dry. The absence of condensation extends the life of the terminal unit, eliminates odours and reduces the possibility of bacterial growth. The space relative humidity is controlled by the primary air. [3]. Induction units are not designed to handle condensation and chilled ceilings must obviously avoid it. Fan coil units may be designed to dehumidify the room air, particularly in far eastern locations, but are generally applied in dry mode in western Europe. The usual exception to this practice is the low budget project, where the significantly higher cooling capacity of the wet fan coil reduces the quantity of units required.

The temperatures required for the secondary cooling water circuit, therefore, must be high enough to prevent condensation on the cooling equipment. ASHRAE [3] recommends that, in the case of chilled ceiling panels the cooling water supply temperature should be at least $0.5{ }^{\circ} \mathrm{C}$

Table 1

One percent external conditions for some European cities with temperate climates [2]

\begin{tabular}{|c|c|c|c|c|c|}
\hline City & $\begin{array}{l}1 \% \text { Dry bulb } \\
\text { temperature }\left({ }^{\circ} \mathrm{C}\right)\end{array}$ & $\begin{array}{l}\text { Mean coincident WBT }\left({ }^{\circ} \mathrm{C}\right) \\
\text { (coincident with the dry bulb temperature) }\end{array}$ & $1 \%$ WBT $\left({ }^{\circ} \mathrm{C}\right)$ & $\begin{array}{l}1 \% \text { Humidity } \\
\text { ratio }(\mathrm{g} / \mathrm{kg})\end{array}$ & $\begin{array}{l}1 \% \text { Dew point } \\
\text { temperature }\end{array}$ \\
\hline Glasgow & 21.6 & 16.0 & 16.7 & 10.7 & 15.0 \\
\hline Dublin & 20.6 & 16.3 & 17.1 & 11.4 & 15.9 \\
\hline Oslo (Fernebo) & 24.8 & 16.4 & 17.4 & 11.2 & 15.8 \\
\hline Copenhagen & 23.2 & 16.4 & 17.4 & 11.0 & 15.5 \\
\hline Helsinki & 24.1 & 16.3 & 17.6 & 11.4 & 15.9 \\
\hline Stockholm (Bromma) & 24.2 & 16.2 & 17.7 & 11.5 & 16.1 \\
\hline London (Heathrow) & 25.7 & 17.7 & 18.7 & 11.9 & 16.7 \\
\hline Kaliningrad & 25.0 & 17.7 & 18.7 & 12.1 & 16.9 \\
\hline Oostende & 23 & 18.2 & 18.8 & 12.5 & 17.5 \\
\hline Hamburg & 25.9 & 18.0 & 18.8 & 12.1 & 16.9 \\
\hline Munich & 27.1 & 18.0 & 18.8 & 12.4 & 16.4 \\
\hline Zurich & 26.4 & 18.1 & 18.9 & 12.8 & 16.8 \\
\hline La Coruna & 23.6 & 18.2 & 19.0 & 12.8 & 17.7 \\
\hline Amsterdam & 24.8 & 18.1 & 19.2 & 12.8 & 17.8 \\
\hline Berlin & 27.9 & 18.1 & 19.2 & 12.1 & 16.9 \\
\hline Brussels & 26.2 & 18.9 & 19.8 & 12.9 & 17.8 \\
\hline Warsaw & 27.0 & 19.0 & 19.9 & 13.0 & 17.9 \\
\hline Paris (Orly) & 28.0 & 19.4 & 20.3 & 13.3 & 18.2 \\
\hline Santander & 24.7 & 19.4 & 20.7 & 14.5 & 19.7 \\
\hline Milan (Linate) & 30.3 & 22.3 & 23.5 & 16.7 & 21.8 \\
\hline
\end{tabular}


above the room air dew point, although a recent research programme [6] concluded that the onset of condensation on the room panel surface did not occur until the cooling water supply temperature was $2 \mathrm{~K}$ below the room air dew point, provided the supply water loop was insulated. Nevertheless, this latter work recommends that the cooling water supply temperature should not be less than the room air dew point temperature to allow for control bands on temperature sensors and local variations in the room conditions. ASHRAE [4] recommends that office buildings in summer be maintained between 23 and $26{ }^{\circ} \mathrm{C}$ and $50-60 \%$ relative humidity. This implies a room air dew point range of $12-$ $17.5^{\circ} \mathrm{C}$. A minimum office condition of $22{ }^{\circ} \mathrm{C}$ and $50 \%$ relative humidity, which is common in western Europe, has a dew point of $11^{\circ} \mathrm{C}$. This implies, therefore, a maximum secondary cooling water temperature range of $11-18{ }^{\circ} \mathrm{C}$ if the CIBSE recommendation is taken for the lower limit of the range and the ASHRAE recommendation for the upper.

The temperatures required for the secondary cooling water circuit also depend on the system employed. For example, dry mode fan coil units require a supply at 10 $14{ }^{\circ} \mathrm{C}$ [1], while chilled ceilings require water at $14-18{ }^{\circ} \mathrm{C}$ [6]. The sensible cooling output of these systems is reduced as the cooling water temperature rises, however this reduction can be compensated for, if required, by increasing the area of the heat transfer surface. The radiant cooling provided by the chilled ceiling panel, however, allows higher room air temperatures to be used, while still maintaining comfort conditions. This, in turn, allows higher cooling water temperatures to be used. A recent CIBSE research report [6] concluded that office buildings with relatively high internal heat gains of $60 \mathrm{~W} / \mathrm{m}^{2}$ and served by high efficiency chilled ceilings panels and beams could maintain reasonable thermal comfort conditions in the space (a transient maximum dry resultant temperature of $25.2{ }^{\circ} \mathrm{C}$ and a predicted mean vote of +0.8 ) with a cooling water supply temperature of $18{ }^{\circ} \mathrm{C}$. This maximum condition was measured between 16:00 and 17:00 $\mathrm{h}$ with lower conditions at other times. This situation is considered acceptable as it implies a predicted percentage dissatisfied of no greater than $20 \%$ for short periods. A newly developed active induction chilled beam [16] can operate successfully with a water supply temperature of $14-18{ }^{\circ} \mathrm{C}$. The cooling output is derated at $18{ }^{\circ} \mathrm{C}$ to about $55 \%$ of its output at $14{ }^{\circ} \mathrm{C}$, however this can be compensated for, if required, by increasing beam length. A temperature of $18{ }^{\circ} \mathrm{C}$ would seem to be the maximum cooling water temperature which can be used with sensible air-water cooling systems, of this type, although this largely depends on the comfort criteria considered acceptable for each project and whether an adaptive approach to comfort conditions could be employed. Two recent research papers state that chilled ceiling panels can operate with a supply water temperature as high as $18-20^{\circ} \mathrm{C}$ $[14,12]$.

These elevated secondary cooling water temperatures raise the possibility of generating the required cooling in cooling towers. Hence, the view has developed that tower based evaporative cooling ought now to be the subject of major review as a practical and low energy means of cooling modern buildings [11]. The changing nature of the cooling load in many new western European office buildings has also helped to reinforce this view. As a result of the deep plan layout, better fabric insulation, high performance glazing and improved standards of air tightness the cooling load in the modern office building is now often dominated by the internally generated sensible load. The internally generated sensible load is derived from the occupants, lighting, IT equipment, other small power loads and is present throughout the year. Hence, the cooling season in such buildings is not necessarily confined to the summer months, but can extends into periods of the year with good evaporative cooling potential due to the lower ambient WBTs experienced.

\section{Background}

Occupancy densities in office buildings vary from a maximum of one person per $7 \mathrm{~m}^{2}$ to a minimum of one person per $19 \mathrm{~m}^{2}$, where there are private offices [4]. Latent cooling loads from occupants in office buildings vary from $50 \mathrm{~W}$ per person at $22^{\circ} \mathrm{C}$ room dry bulb temperature to $70 \mathrm{~W}$ per person at $26^{\circ} \mathrm{C}$ [8]. This implies a latent cooling load from occupants ranging from 2.6 to $10 \mathrm{~W} / \mathrm{m}^{2}$. Unless, therefore, there is an exceptionally high occupancy density or an exceptional activity which produces a high metabolic rate, the internal latent cooling loads in office buildings constitute a minor portion of the total cooling load. External latent cooling loads are also generally small in moderate thermal climates, as indicated in Table 1, which shows the current $1 \%$ external design condition for a number of large west European cities with temperate and generally maritime climates [2]. The table is in ascending order of the $1 \%$ WBT. A typical internal summer condition of $24{ }^{\circ} \mathrm{C}$ air temperature and $60 \%$ relative humidity has a dew point temperature of $15.7^{\circ} \mathrm{C}$ and a humidity ratio of $11.2 \mathrm{~g} / \mathrm{kg}$. As can be seen, with reference to Table 1 , the external moisture content of the air is generally not at a level which will produce, of itself, a large latent gain to the space. In general, therefore, the cooling loads in commercial buildings, which are located in regions with moderate external summer conditions and with normal occupancy densities are composed largely of sensible heat gains. Such buildings are particularly suited to airwater air conditioning systems due to the low ventilation supply rates required, and the dominance of the sensible component of the total cooling load.

A crucial feature of the feasibility of evaporative cooling in temperate climates is the achievement of a low temperature difference between the water exiting from the cooling tower and the ambient WBT (the primary approach temperature, PAT). This is necessary, in order to ensure, a significant level of cooling water availability, especially 


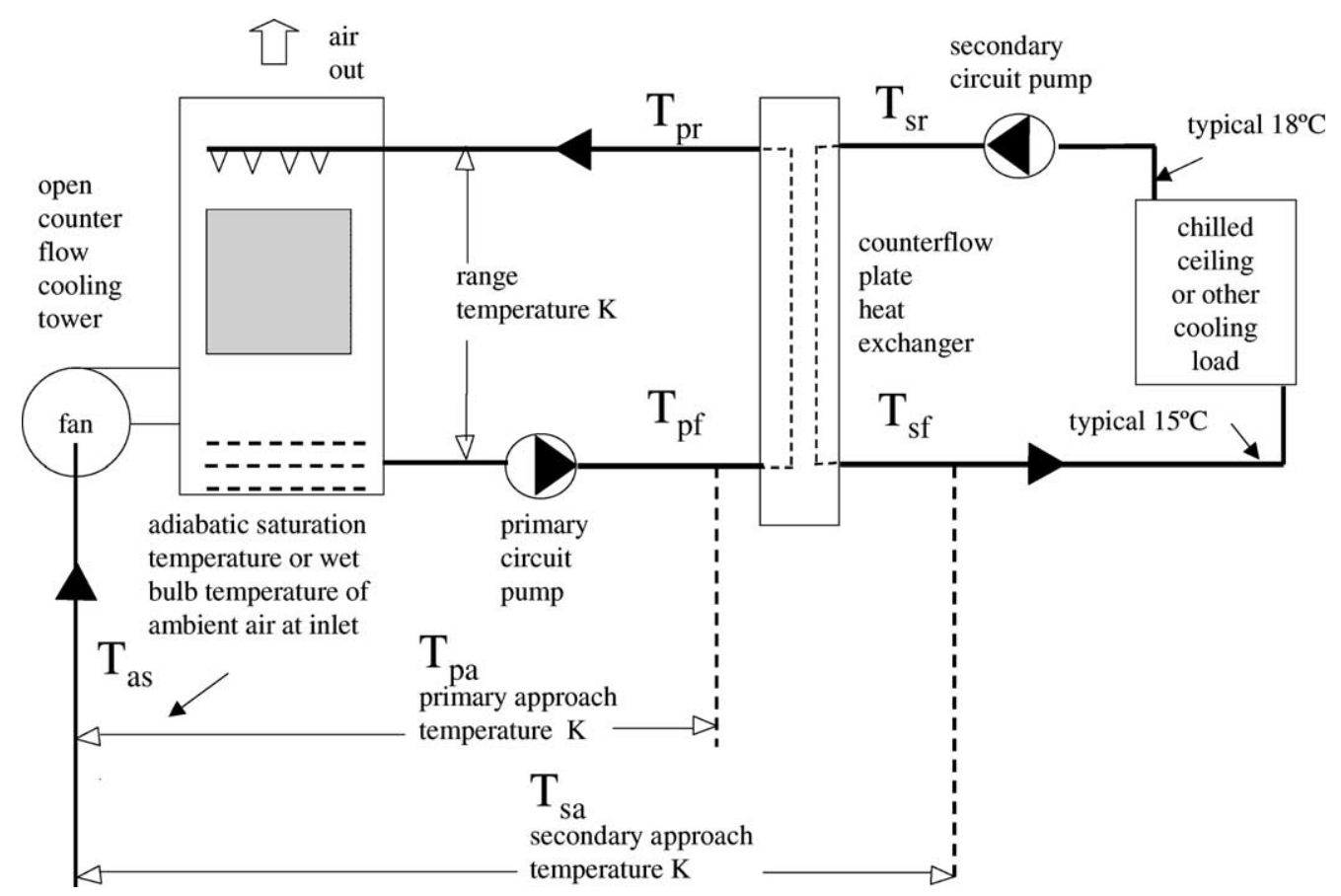

Fig. 1. Simplified schematic of indirect evaporative cooling system (IDEC).

in summer, when ambient WBTs are high. This aspect is complicated by the requirement, in contemporary applications, to separate the tower water circuit from the building cooling circuit by means of a heat exchanger. Hence, the crucial design parameter becomes the temperature difference between the water exiting from the heat exchanger and the ambient WBT (the secondary approach temperature, SAT). Fig. 1, which shows a simplified schematic of a typical indirect evaporative cooling system, indicates the relevant design parameters.

At present, however, there is little in-depth research and analysis of the performance, energy efficiency and year round availability of this alternative form of cooling, especially in temperate climates, at very low approach and range conditions and at WBTs below $16^{\circ} \mathrm{C}$. To address these issues, an experimental research programme has been established with a view to demonstrating the potential and optimising the design of this form of cooling in modern deep plan buildings. This programme is based on an open counter-flow cooling tower, optimised for close approach conditions and incorporating a plate heat exchanger, also designed for close approach conditions. The tower dimensions are $0.9 \mathrm{~m}$ wide, $1.2 \mathrm{~m}$ deep and $3.2 \mathrm{~m}$ high. Automatic data logging of all key variables is also incorporated in the test rig. Modulated speed control of the cooling tower fan is achieved by inverter control of the fan motor. The cooling load is provided by an in-line electric immersion heater, with modulated thyristor control. This enables the imposed cooling load on the tower to be accurately measured and controlled, and the energy performance of the process to be accurately monitored. Test results are analysed using computer software and meteorological test reference year (TRY) data. The design and performance of the rig is described in detail elsewhere [10]. Fig. 2 shows a schematic diagram of the evaporative cooling experimental test rig. A key issue in this research is the detailed evaluation of the extent of cooling availability which can be expected for various locations, types of cooling system, and for a range of cooling water supply temperatures.

\section{Experimental programme results}

The use of cooling towers in this application requires data on thermal performance in conditions well outside those normally encountered in refrigeration condenser heat rejection. In low approach indirect evaporative cooling primary water temperatures are much lower, ranging from 9 to $17^{\circ} \mathrm{C}$ compared with $25-45^{\circ} \mathrm{C}$ in condenser water cooling. Design range temperatures are also much lower with values as low as $1.8 \mathrm{~K}$ compared with typical values of $6 \mathrm{~K}$ for condenser cooling circuits. This results in smaller enthalpy difference driving forces in the tower and therefore smaller heat and mass transfer rates. Ambient WBTs are also low ranging from 7 to $17{ }^{\circ} \mathrm{C}$ throughout the year. As manufactures performance data for cooling towers is generally limited to approach and range conditions above $3 \mathrm{~K}$ and WBTs above $17^{\circ} \mathrm{C}$ there is a need for experimental data on cooling tower performance at low approach temperatures and at the conditions encountered in indirect evaporative cooling of buildings, in temperate climates, throughout the year. Goshayshi et al. [15] suggests that PATs of less than $3 \mathrm{~K}$ may be achieved in this application by enhancing heat transfer in the tower packing. However, in the absence of 


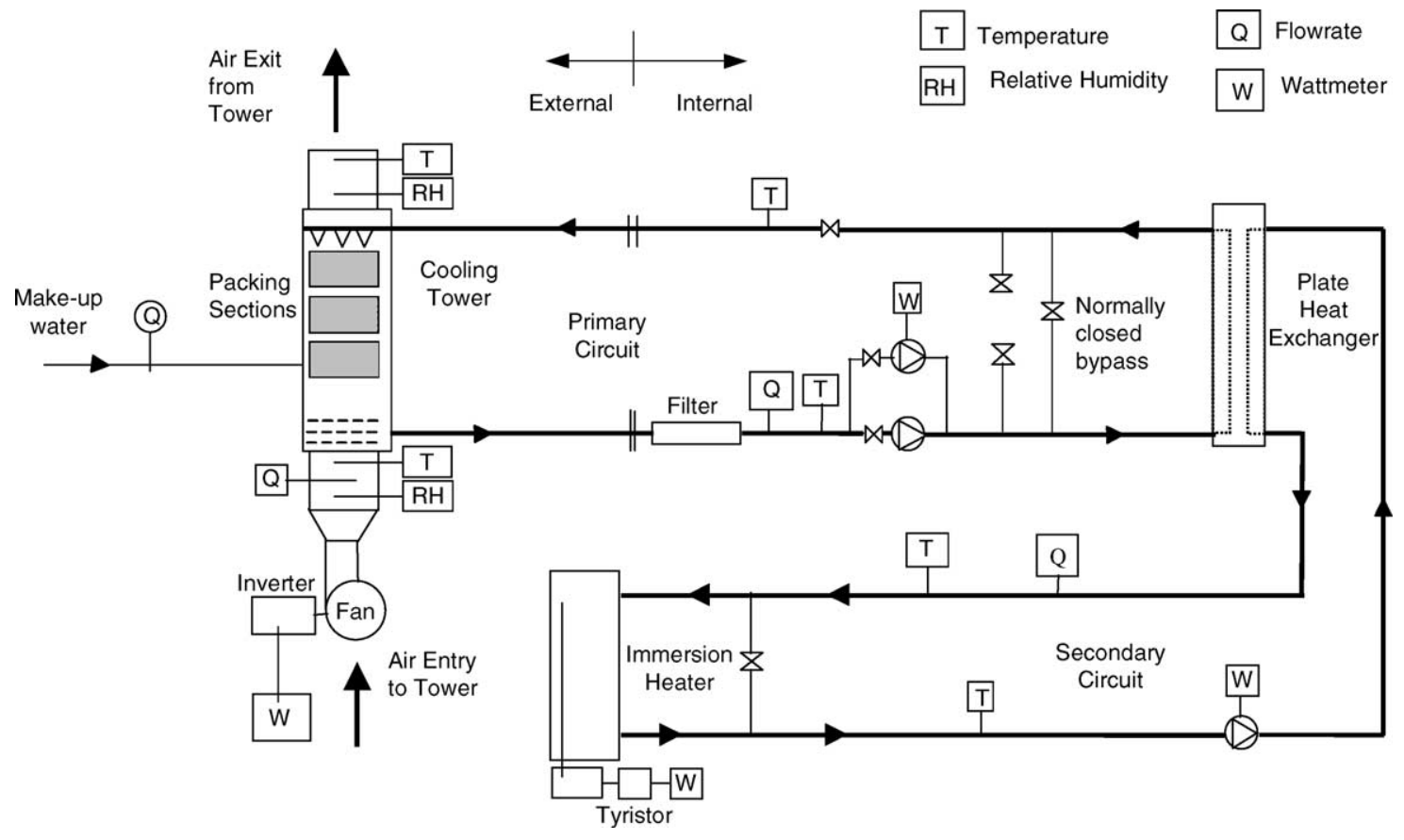

Fig. 2. Schematic diagram of evaporative cooling experimental test rig.

such experimental data, existing work in this area is generally based on extrapolating thermal performance from conventional equipment and conditions. This is the general approach of Butler [5] who uses a SAT of $4.5 \mathrm{~K}$ on the basis that this value is practical and economic. Murphy [19] uses a value of $4.1 \mathrm{~K}$, based on a selected PAT of $3 \mathrm{~K}$ and a temperature difference of $1.1 \mathrm{~K}$ across the heat exchanger.

Recent experimental research, however, [10] has shown that it is possible to design an indirect heat rejection system, based on close approach principles and utilising high contact area plate heat exchangers in conjunction with enhanced evaporative heat transfer in open, counter-flow, cooling towers, which is capable of generating secondary cooling water at a temperature of $3 \mathrm{~K}$ above the ambient adiabatic saturation temperature (AST) at viable heat rejection rates of $1 \mathrm{~kW}$ per $0.05 \mathrm{~m}^{3}$ of tower packing volume and with a packing surface area of $200 \mathrm{~m}^{2} / \mathrm{m}^{3}$. This is significantly less than the SATs previously used and raises the availability level above that previously considered viable. A summary of some typical experimental test results is shown in Table 2.

Figs. 3-5 show the diurnal variation in conditions during three typical daily tests. Table 2 confirms that a PAT of no greater than $1.5 \mathrm{~K}$ and a SAT of no greater than $3 \mathrm{~K}$ is feasible for a $20 \mathrm{~kW}$ load, when the heat rejection circuit is designed on close approach principles. Figs. 3-5 and Table 2 show how the secondary flow temperature tracks the ambient AST, rather than the more widely fluctuating ambient dry bulb temperature. This research confirms that open cooling towers, incorporating modern high surface density packing

Table 2

Summary of experimental test results from prototype cooling tower test rig (Dublin)

\begin{tabular}{lrllll}
\hline $\begin{array}{l}\text { Nominal } \\
\text { load }(\mathrm{kW})\end{array}$ & AST $\left({ }^{\circ} \mathrm{C}\right)$ & $\begin{array}{l}\text { Primary flow temperature } \\
\text { from tower }\left({ }^{\circ} \mathrm{C}\right)\end{array}$ & $\begin{array}{l}\text { Secondary flow temperature } \\
\text { from heat exchanger }\left({ }^{\circ} \mathrm{C}\right)\end{array}$ & $\begin{array}{l}\text { Primary approach } \\
\text { to AST (K) }\end{array}$ & $\begin{array}{l}\text { Secondary approach } \\
\text { to AST }(\mathrm{K})\end{array}$ \\
\hline 24 & 6.4 & 8.7 & 10.7 & 2.3 & 4.3 \\
24 & 8.9 & 10.8 & 12.5 & 1.9 & 3.9 \\
24 & 9.2 & 11.1 & 12.8 & 1.7 & 3.6 \\
24 & 11.1 & 12.8 & 14.6 & 1.4 & 3.5 \\
20 & 8.4 & 9.8 & 11.3 & 1.4 & 2.9 \\
20 & 9.2 & 10.6 & 12.1 & 1.1 & 2.9 \\
20 & 10.2 & 11.3 & 12.9 & 1.0 & 2.7 \\
20 & 12.5 & 13.5 & 15.1 & 0.9 & 2.6 \\
20 & 16.5 & 17.4 & 19.0 & 1.0 & 2.5 \\
15 & 8.7 & 9.7 & 10.9 & 1.3 & 2.3 \\
15 & 9.3 & 10.6 & 11.7 & 1.4 & 2.4 \\
15 & 9.7 & 11.1 & 12.3 & 1.0 & 2.6 \\
15 & 10.6 & 11.6 & 12.8 & & 2.2 \\
\hline
\end{tabular}




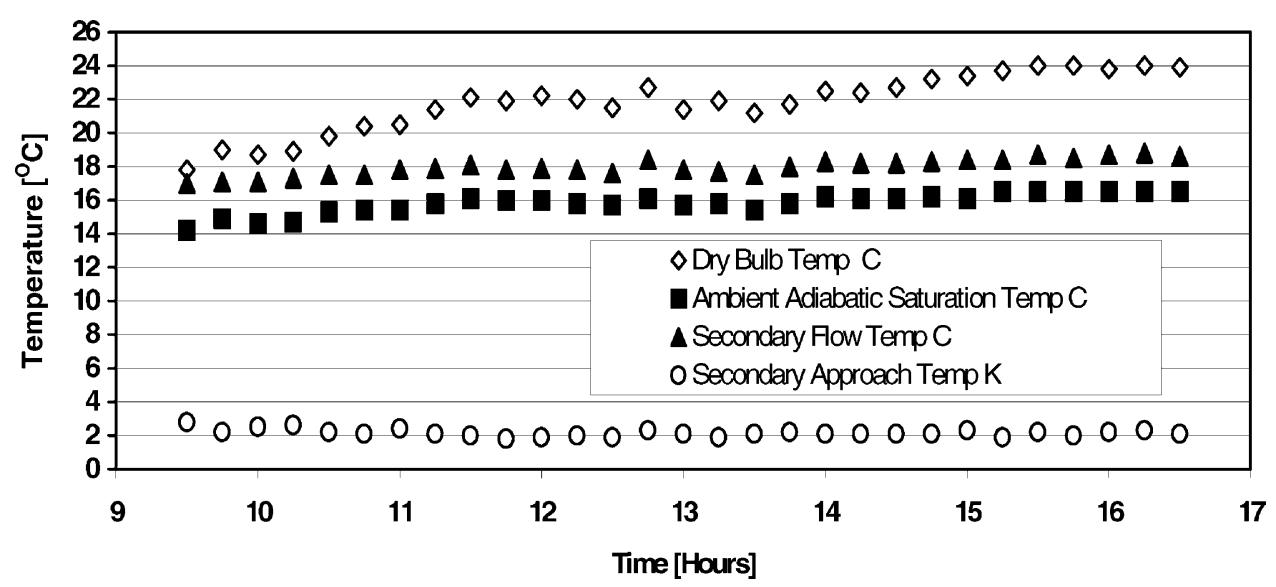

Fig. 3. Measured diurnal variation in conditions for 1 August 2000, in Dublin at a constant $20 \mathrm{~kW}$ load and maximum fan power (Dublin design day conditions).

designs, and operating under very close approach conditions perform, in this respect, in a manner similar to conventional wide approach towers, for which the dependence of the exiting water temperature on the ambient AST or WBT is well established [3].

A feature of the test results shown in Table 2 is the seeming small dependence of the approach condition on the absolute value of the ambient AST at the 24 and $20 \mathrm{~kW}$ load. The approach condition seems to fall marginally as the absolute value of the ambient AST rises. The trend would seem to favour the evaporative cooling of buildings as the lowest approach conditions occur during periods of highest external heat gains. This feature was also recently reported by Facao and Oliveira [12] in the context of the application of closed wet cooling towers to the generation of cooling water for use with chilled ceilings. Facao reports an approximate $8 \%$ increase in tower thermal efficiency when the
WBT rises from 10 to $20{ }^{\circ} \mathrm{C}$. The increase is linear and the influence similar at different air and water mass flow rates.

In both Figs. 3 and 4 the cooling load was $20 \mathrm{~kW}$ and the tower fan power input was at maximum value. In Fig. 5 the cooling load was reduced to $14 \mathrm{~kW}$ (representing a $70 \%$ partial load condition) and the fan power input was reduced to $60 \%$ of the maximum value. The approach temperature achieved depends on the fan power input level, which, in turn, affects the resulting energy efficiency. The energy performance of the process is described, in detail, elsewhere [9]. Fig. 3 can be considered to represent a typical design day in Dublin, with ambient dry bulb temperatures reaching $24{ }^{\circ} \mathrm{C}$ and WBTs reaching $17{ }^{\circ} \mathrm{C}$. Nevertheless, it was possible, under these conditions, to produce cooling water temperatures of $17-19{ }^{\circ} \mathrm{C}$, which could provide or contribute towards building cooling, depending on the internal conditions considered acceptable. This demonstrates the

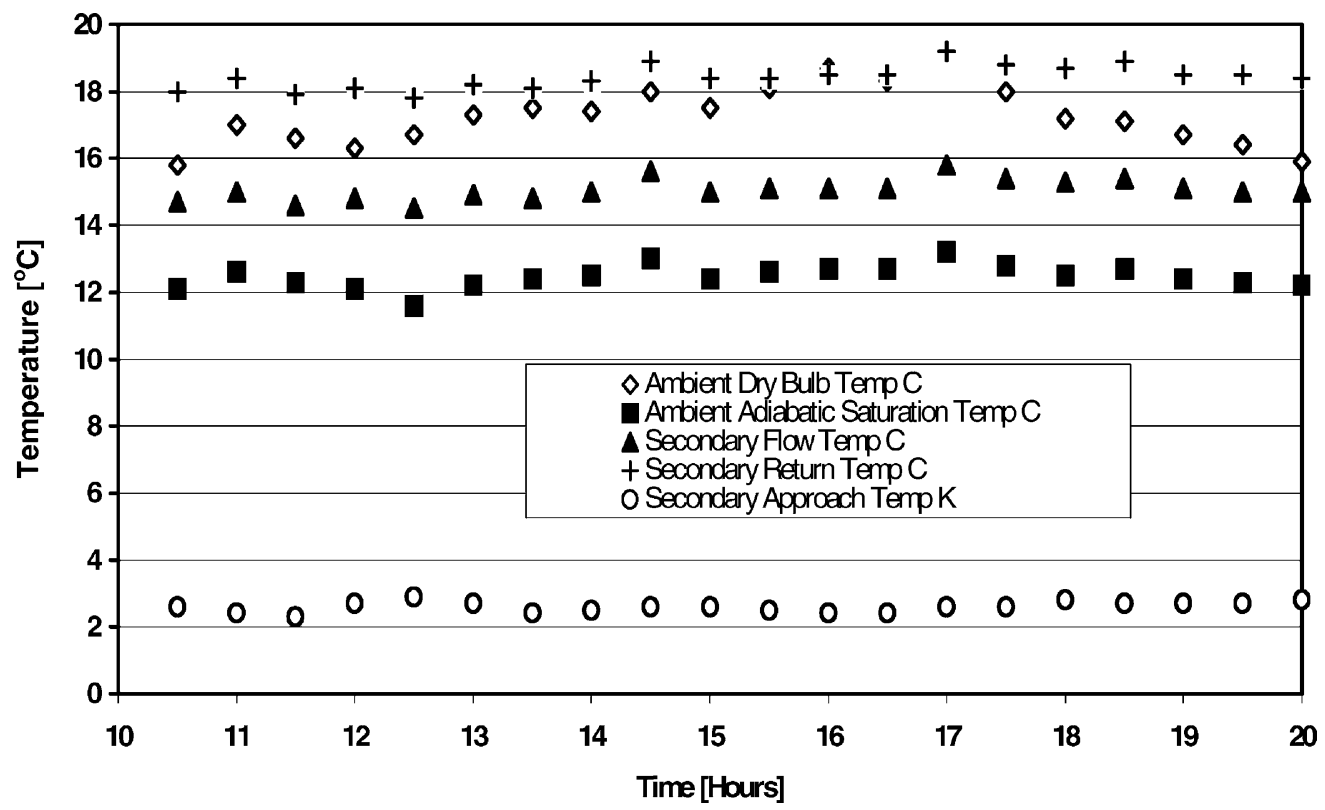

Fig. 4. Measured diurnal variation in conditions for 6 September 2000, in Dublin at a constant $20 \mathrm{~kW}$ and maximum fan power. 


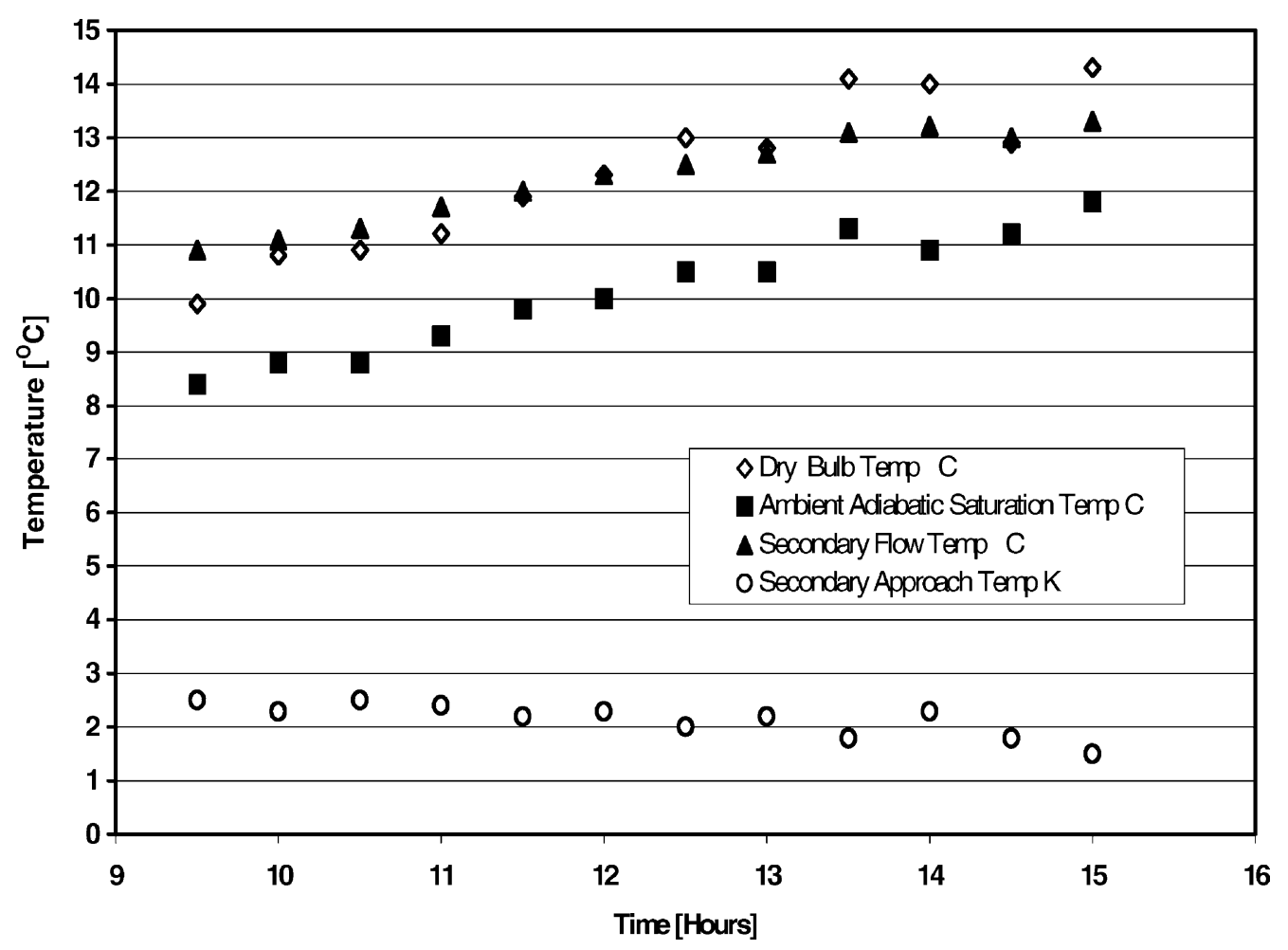

Fig. 5. Measured diurnal variation in conditions for 25 October 2000, in Dublin at a constant $14 \mathrm{~kW}$ load and $60 \%$ fan power.

technical feasibility of the process, even at summer design conditions for this location. In the Fig. 4 test, secondary cooling water temperatures of $15-16{ }^{\circ} \mathrm{C}$ were produced in September, which would be suitable for many chilled ceiling applications, while in the Fig. 5 test, secondary cooling water temperatures of $11-13{ }^{\circ} \mathrm{C}$ were produced in October, a condition which would suit a dry mode fan coil application.

\section{Availability analysis}

\subsection{Determination of adiabatic saturation temperature}

In order to quantify the evaporative cooling availability which can be expected for any given location it is, therefore, necessary to establish the typical yearly record pattern of the ambient AST. This can be achieved by using, either a meteorological test reference weather year or alternatively, where such is available, an hourly record of ambient WBTs over a standard 30 year period. The TRY method has been used in this analysis as it is now readily available in software format for a wide range of world wide locations.

A TRY consists of a data base record of hourly weather data for 12 typical months forming a composite year. Each month is chosen on the basis of its statistical typicality. The data are intended for use in computer programmes concerned with energy load and local climate analysis. The data are applicable to these locations and for a limited area around these locations. The hourly weather records typically include data on dry bulb temperature, relative humidity, wind speed and solar radiation. By using the dry bulb temperature and relative humidity listed in the original TRY, a new TRY has been developed which lists a range of standard psychrometric properties. These properties have been determined from the fundamental psychrometric equations involved [2] and include the atmospheric pressure corrected for height above mean sea level (67 $\mathrm{m}$ for Dublin and $122 \mathrm{~m}$ for Milan). The determination of the AST required an iteration of the fundamental equations in a separate software routine. A sample of data from the new TRY developed is shown in Appendix A. The difference between the AST and WBT is generally less than $0.25 \mathrm{~K}$ for dry bulb temperatures above $0{ }^{\circ} \mathrm{C}$, where the wet bulb depression is less than $11 \mathrm{~K}$ and where no unusual radiation circumstances exist [18]. Hence, for the purpose of this analysis the WBT can be considered equal to the AST without significant error. The AST is used in this analysis as it is a fundamental property of the air which, unlike the WBT, can be determined without recourse to empirical quantities and does not depend on specific air velocities or heat and mass transfer rates.

\subsection{Evaporative cooling potential}

Having established the new psychrometric TRY for the site, the data can now be analysed to determine the evaporative cooling potential. In the first instance the occurrence of the ambient AST is calculated and then, using a $3 \mathrm{~K}$ SAT the potential for cooling water generation is determined. 


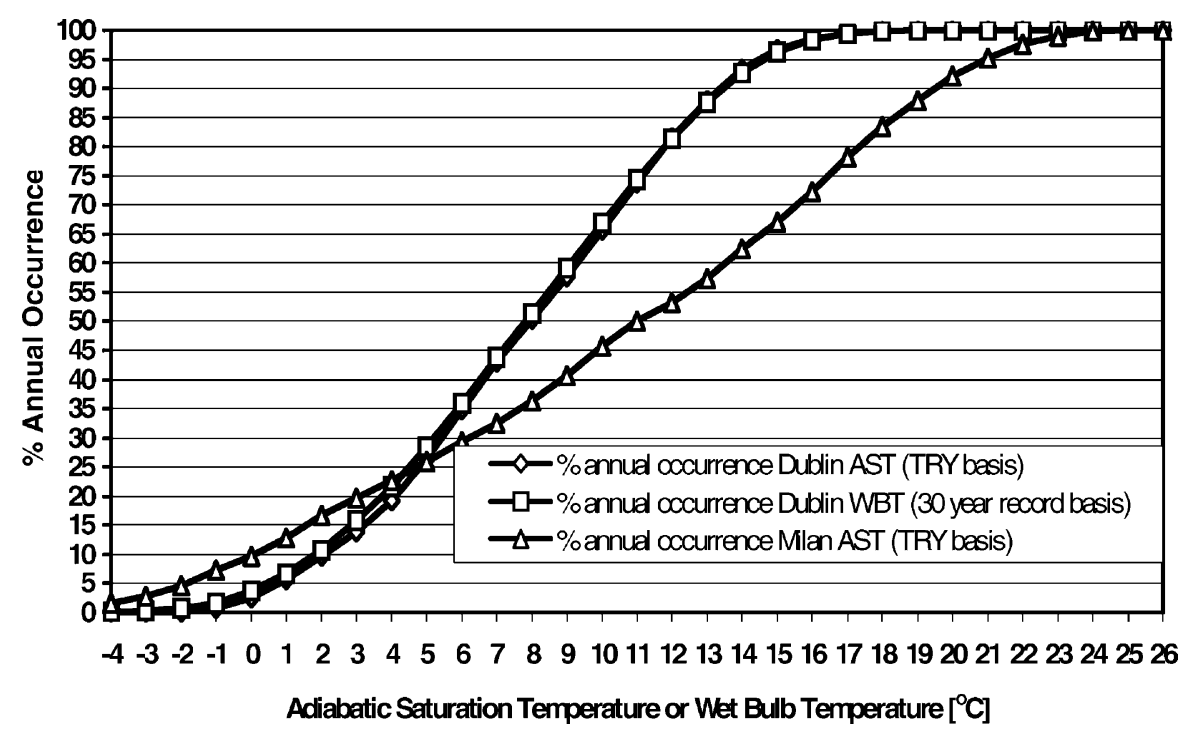

Fig. 6. Percentage annual occurrence of AST in Milan and AST with WBT in Dublin.

Fig. 6 shows the percentage occurrence of the AST for Dublin and Milan based on the hourly measurement of the ambient condition as contained in the TRY data. Also shown is the percentage occurrence of the hourly WBT for Dublin based on a thirty year period (1966-1995). The results show that the AST of $13{ }^{\circ} \mathrm{C}$ (required to supply cooling water at $16{ }^{\circ} \mathrm{C}$ to chilled ceiling panels) is statistically available for $57.3 \%$ of the year in Milan, $88 \%$ of the year in Dublin on an AST TRY basis and $87.7 \%$ of the year in Dublin on a 30 year wet bulb occurrence basis. There is a very close correlation between the AST and WBT occurrence results for Dublin, which confirms the approach, described above, of using the AST, derived from the TRY, as the basis for assessing the evaporative cooling potential. The annual occurrence is calculated on a $24 \mathrm{~h}$ day basis and is defined as the percentage of the total annual hours $(8760 \mathrm{~h})$ during which, a temperature at or below a particular temperature, occurs.

The potential for cooling water generation is analysed as follows:

- Total annual availability at a range of SAT.

- Annual availability at the minimum 3 K SAT.

- Average monthly cooling water temperatures at $3 \mathrm{~K}$ SAT.

- Variation of average monthly cooling water temperature with length and time of day.

- Analysis of unavailability, particularly in summer, at high cooling water temperatures.

- Assessment of the penalty imposed by the indirect system in terms of the diminished cooling availability which results.

\subsection{Annual availability of cooling potential}

The percentage annual availability of cooling water $(A)$ is defined as:

$A=\frac{\left[100 \sum\left(H_{\mathrm{tas}}\right)\right]}{8760}$ where $\Sigma\left(H_{\text {tas }}\right)$ is the statistically typical (on a TRY basis) total number of annual hours, during which, the ambient AST is less than or equal to $\left(T_{\mathrm{sf}}-T_{\mathrm{sa}}\right) . T_{\mathrm{sf}}$ is the secondary flow temperature $\left({ }^{\circ} \mathrm{C}\right), T_{\mathrm{sa}}$ the SAT $(\mathrm{K}), 8760$ the number of hours in a year.

Availability of cooling water at any given temperature is significantly increased by reducing the SAT. Figs. 7 and 8 show the impact on availability of reducing the SAT from a more conventional 8 to the $3 \mathrm{~K}$ outlined in this work. Availability of cooling water at $16{ }^{\circ} \mathrm{C}$ increases from $36.4 \%$ in Milan at $8 \mathrm{~K}$ SAT to $57.3 \%$ at $3 \mathrm{~K}$, while in Dublin at the same conditions availability increases from 50.4 to $88 \%$. The benefits which can be obtained by reducing the SAT are greatest at low cooling water temperatures, in Dublin, however, as the cooling water temperature rises the benefit diminishes, particularly at low SATs. The relationship between the SAT and the percentage availability is approximately linear at all cooling water temperatures between 4 and $18{ }^{\circ} \mathrm{C}$, for Milan. Fig. 7 shows the percentage availability at each temperature and the associated linear regression lines for Milan. These graphs, show an accurate and consistent linear relationship between availability and SAT at all cooling water temperatures shown, with the possible exception of $4{ }^{\circ} \mathrm{C}$. A further aspect of the relationship is that the slope of the regression line rises consistently from -2.5 to -5.0 between 4 and $18{ }^{\circ} \mathrm{C}$. cooling water temperature.

Fig. 8 shows the percentage availability at each temperature and the associated regression lines for Dublin. In the case of Dublin only two of the regression graphs display a linear relationship, those for 12 and $14{ }^{\circ} \mathrm{C}$. All the remaining cooling water temperatures, display, as shown, a close correlation with second order polynomial regression lines. As shown in Fig. 8 the slope of the availability graph increases as the approach temperature is reduced, at low cooling water temperatures, the slope remains constant 


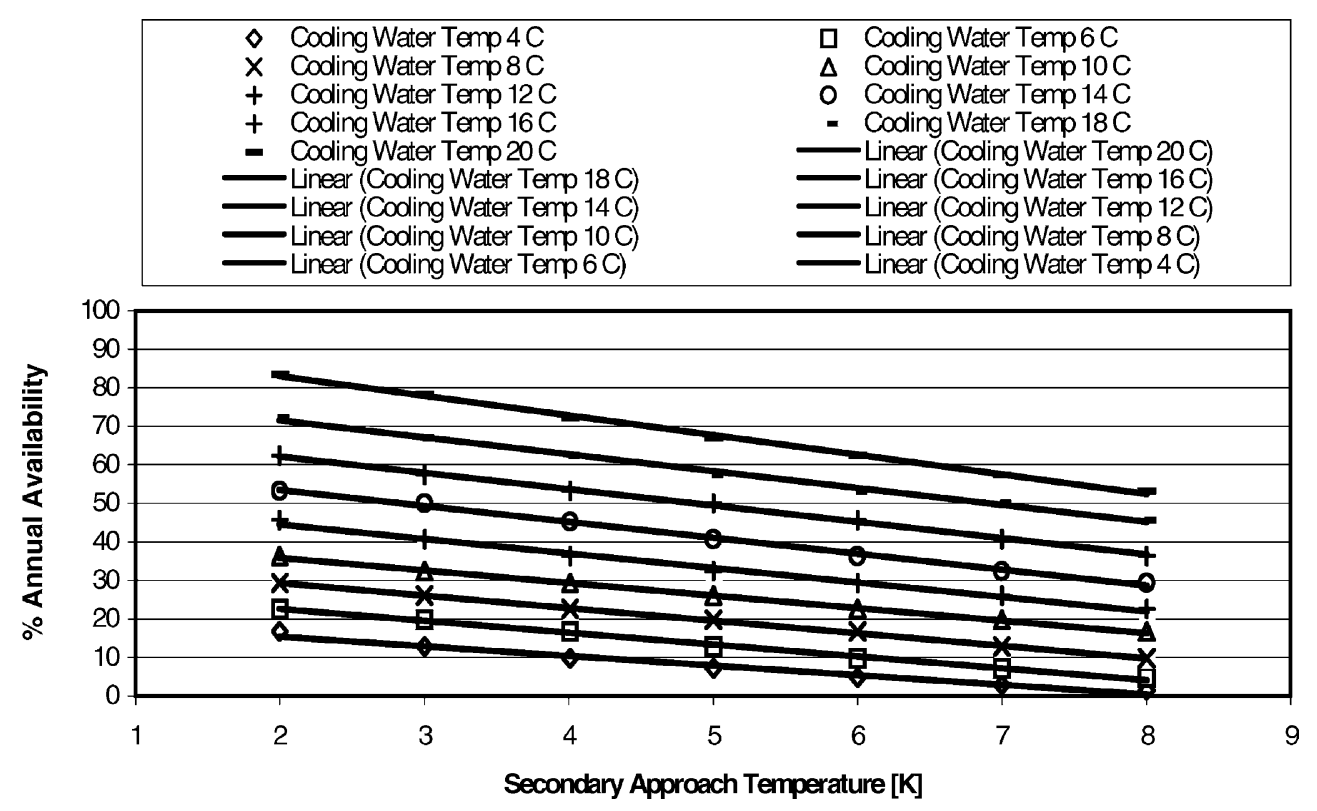

Fig. 7. Impact of secondary approach temperature on percentage annual availability of cooling water in Milan.

between 12 and $14{ }^{\circ} \mathrm{C}$ and decreases at higher cooling water temperatures. Hence, for fan coil system temperatures, there is a linear rise in availability as the SAT falls, but for chilled ceiling system temperatures the incremental rise in availability diminishes, as the SAT falls. At cooling water temperatures below $10{ }^{\circ} \mathrm{C}$, however, the incremental rise in availability increases as the approach temperature falls, indicating the significant benefits, which can be obtained, from low SATs, at lower cooling water temperatures, in
Dublin. For a cooling water temperature of $10^{\circ} \mathrm{C}$, for example, in Dublin, the annual availability rises from $10 \%$ at a SAT of $8 \mathrm{~K}$ to $50 \%$ at an approach of $2 \mathrm{~K}$. In Milan, at similar conditions, the availability rises from 15 to $35 \%$.

While Fig. 7 for Milan might seem, on initial examination, to display a significantly different relationship between SAT and percentage availability, from that shown in Fig. 8 for Dublin, a more detailed analysis of the Milan data, shown
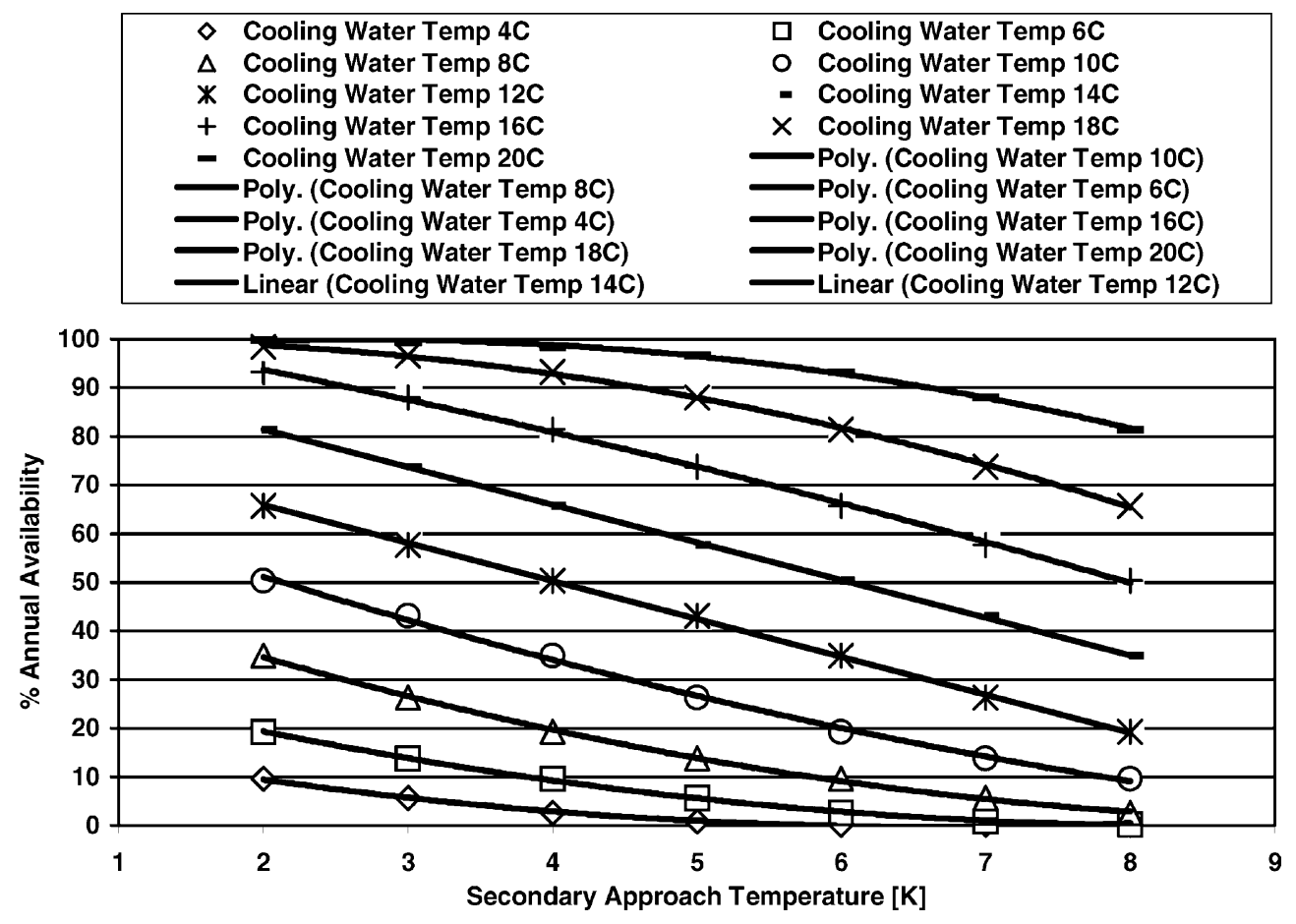

Fig. 8. Impact of secondary approach temperature on percentage annual availability of cooling water in Dublin. 
Table 3

Annual availability potential of cooling water in Dublin at 3 K SAT (percentages)

\begin{tabular}{|c|c|c|c|c|c|c|c|c|c|c|c|c|c|}
\hline \multirow[t]{2}{*}{ Month } & \multicolumn{13}{|c|}{ Cooling water temperature $\left({ }^{\circ} \mathrm{C}\right)$} \\
\hline & -2 & 0 & 2 & 4 & 6 & 8 & 10 & 12 & 14 & 16 & 18 & 20 & 22 \\
\hline January & 0 & 1 & 3 & 8 & 24 & 46 & 74 & 91 & 98 & 100 & 100 & 100 & 100 \\
\hline February & 0 & 0 & 0 & 7 & 26 & 49 & 79 & 99 & 100 & 100 & 100 & 100 & 100 \\
\hline March & 0 & 0 & 0 & 8 & 25 & 52 & 85 & 97 & 100 & 100 & 100 & 100 & 100 \\
\hline April & 0 & 0 & 2 & 8 & 21 & 49 & 79 & 84 & 97 & 100 & 100 & 100 & 100 \\
\hline May & 0 & 0 & 0 & 0 & 1 & 7 & 23 & 59 & 90 & 100 & 100 & 100 & 100 \\
\hline June & 0 & 0 & 0 & 0 & 0 & 1 & 3 & 25 & 71 & 92 & 99 & 100 & 100 \\
\hline July & 0 & 0 & 0 & 0 & 0 & 0 & 1 & 4 & 18 & 52 & 80 & 95 & 100 \\
\hline August & 0 & 0 & 0 & 0 & 0 & 0 & 0 & 2 & 14 & 52 & 90 & 99 & 100 \\
\hline September & 0 & 0 & 0 & 0 & 1 & 3 & 12 & 24 & 44 & 74 & 91 & 99 & 100 \\
\hline October & 0 & 0 & 0 & 0 & 1 & 9 & 24 & 43 & 66 & 89 & 99 & 100 & 100 \\
\hline November & 0 & 0 & 3 & 14 & 27 & 43 & 61 & 76 & 88 & 99 & 100 & 100 & 100 \\
\hline December & 0 & 1 & 3 & 24 & 40 & 60 & 79 & 92 & 100 & 100 & 100 & 100 & 100 \\
\hline Annual (\%) & 0 & 0 & 1 & 6 & 14 & 26 & 43 & 58 & 74 & 88 & 97 & 99 & 100 \\
\hline
\end{tabular}

in Appendix A, Fig. 18 indicates that both relationships are seen to be fundamentally similar, when the full range of possible cooling water temperatures is analysed. The underlying fundamental relationship reveals an increasing rate of rise in availability, with falling SAT, at low cooling water temperature. This is followed by a constant rate of rise in availability at middle range temperatures, and a falling rate of rise at high temperatures. In the case of Milan, it happens that the middle linear range coincides with the range of water temperatures of interest in evaporative cooling applications, at a $3 \mathrm{~K}$ SAT condition.

The two different patterns for Milan and Dublin are explained with reference to Fig. 6, which shows the AST annual occurrence for both locations. The long linear relationship between AST and occurrence which extends from 4 to $16^{\circ} \mathrm{C}$ in Milan, contrasts with the short linear relationship between 7 and $13{ }^{\circ} \mathrm{C}$ for Dublin. This fundamental meteorological relationship sets the limits of the pattern of the correlation between SAT and percentage availability shown in Figs. 7 and 8, as the SAT itself, being a mechanical property of the equipment, is under the control of the designer. Clearly then the most desirable pattern, from the point of view of evaporative cooling, is one in which the increasing rate of rise in availability, as SAT falls extends significantly into the evaporative cooling application range of $11-18{ }^{\circ} \mathrm{C}$. For this to occur the typical early curve of the "S" pattern occurrence graph would need to dominate, virtually eliminating the linear region, and with a short late curve to $100 \%$ occurrence. This analysis can be used to identify those locations in which a low secondary approach is viable and which would benefit most from evaporative cooling.

On the basis of a minimum $3 \mathrm{~K}$ SAT the maximum percentage availability for Dublin and Milan can be determined as shown in Tables 3 and 4 for each month. Both tables show the limits of the process. In Dublin there is no availability at a cooling water temperature of $-2{ }^{\circ} \mathrm{C}$ and $100 \%$ availability, at all months, at a cooling water

Table 4

Annual availability potential of cooling water in Milan at $3 \mathrm{~K}$ SAT (percentages)

\begin{tabular}{|c|c|c|c|c|c|c|c|c|c|c|c|c|c|c|c|c|c|c|c|}
\hline \multirow[t]{2}{*}{ Month } & \multicolumn{19}{|c|}{ Cooling water temperature $\left({ }^{\circ} \mathrm{C}\right)$} \\
\hline & -8 & -6 & -4 & -2 & 0 & 2 & 4 & 6 & 8 & 10 & 12 & 14 & 16 & 18 & 20 & 22 & 24 & 26 & 28 \\
\hline January & 0 & 1 & 5 & 9 & 20 & 37 & 57 & 77 & 95 & 100 & 100 & 100 & 100 & 100 & 100 & 100 & 100 & 100 & 100 \\
\hline February & 0 & 0 & 0 & 0 & 6 & 20 & 42 & 65 & 81 & 95 & 99 & 100 & 100 & 100 & 100 & 100 & 100 & 100 & 100 \\
\hline March & 0 & 0 & 0 & 0 & 0 & 0 & 3 & 10 & 21 & 41 & 72 & 94 & 100 & 100 & 100 & 100 & 100 & 100 & 100 \\
\hline April & 0 & 0 & 0 & 0 & 0 & 0 & 0 & 1 & 4 & 15 & 34 & 54 & 72 & 91 & 99 & 100 & 100 & 100 & 100 \\
\hline May & 0 & 0 & 0 & 0 & 0 & 0 & 0 & 0 & 0 & 1 & 9 & 22 & 45 & 69 & 91 & 100 & 100 & 100 & 100 \\
\hline June & 0 & 0 & 0 & 0 & 0 & 0 & 0 & 0 & 0 & 0 & 0 & 0 & 3 & 26 & 49 & 72 & 90 & 97 & 100 \\
\hline July & 0 & 0 & 0 & 0 & 0 & 0 & 0 & 0 & 0 & 0 & 0 & 4 & 10 & 19 & 35 & 61 & 83 & 97 & 100 \\
\hline August & 0 & 0 & 0 & 0 & 0 & 0 & 0 & 0 & 0 & 0 & 0 & 0 & 1 & 5 & 22 & 52 & 81 & 97 & 100 \\
\hline September & 0 & 0 & 0 & 0 & 0 & 0 & 0 & 0 & 0 & 0 & 0 & 0 & 4 & 21 & 48 & 72 & 88 & 98 & 100 \\
\hline October & 0 & 0 & 0 & 0 & 0 & 0 & 0 & 0 & 4 & 6 & 13 & 38 & 59 & 76 & 95 & 100 & 100 & 100 & 100 \\
\hline November & 0 & 0 & 0 & 0 & 1 & 2 & 7 & 17 & 29 & 49 & 72 & 92 & 97 & 100 & 100 & 100 & 100 & 100 & 100 \\
\hline December & 0 & 0 & 0 & 1 & 8 & 27 & 46 & 68 & 82 & 86 & 93 & 100 & 100 & 100 & 100 & 100 & 100 & 100 & 100 \\
\hline Annual (\%) & 0 & 0 & 0 & 1 & 3 & 7 & 13 & 20 & 26 & 32 & 41 & 50 & 57 & 67 & 78 & 88 & 95 & 99 & 100 \\
\hline
\end{tabular}


temperature of $22{ }^{\circ} \mathrm{C}$. In Milan similar limits are -8 and $28{ }^{\circ} \mathrm{C}$. Water temperatures below $0{ }^{\circ} \mathrm{C}$ are included in order to show the full range of the potential. The importance of maximising design cooling water temperatures, in order to increase availability, is clearly shown. For example, the result of raising the design cooling water temperature from 14 to $16{ }^{\circ} \mathrm{C}$ with chilled ceiling systems, in Dublin, is to greatly increase availability from June to October. The low potential for evaporative cooling of supply water in Milan from June to September is also demonstrated, in Table 4, as is the significant potential for return water cooling (load shaving), with higher temperature chilled ceilings, during these months. The potential to generate cooling water even at $18{ }^{\circ} \mathrm{C}$ is small in Milan in summer. However, this potential is increased by approximately a factor of two at $20{ }^{\circ} \mathrm{C}$. Hence, while there is limited potential for evaporative cooling acting alone there is significant potential for pre-cooling the secondary water loop to 19 or $20{ }^{\circ} \mathrm{C}$ prior to refrigeration cooling to $18{ }^{\circ} \mathrm{C}$. However, if an adaptive approach to comfort could be employed with cooling water supply loop temperatures of $20^{\circ} \mathrm{C}$, returning at $23{ }^{\circ} \mathrm{C}$, then the evaporative cooling technique offers major potential for load shaving throughout the summer months, in Milan, with availability levels for full or partial cooling by evaporation of at least $50 \%$.

On the basis of this analysis the ranges of cooling water temperatures which can be achieved, throughout the year, for each location are shown in Table 5. The temperature shown is the approximate range which can be achieved with a SAT of $3 \mathrm{~K}$ over the $24 \mathrm{~h}$ period, and for an availability level of $90 \%$ or greater.

\subsection{Annual distribution of cooling potential}

The cooling water temperature generated by evaporation varies over the course of the day in response to the changing
Table 5

Cooling water temperatures achievable throughout the year with $90 \%$ or greater availability, based on a SAT of $3 \mathrm{~K}$

\begin{tabular}{lll}
\hline $\begin{array}{l}\text { Cooling water temperature } \\
\text { achievable }\left({ }^{\circ} \mathrm{C}\right)\end{array}$ & Dublin & Milan \\
\hline 8 & & January \\
10 & & $\begin{array}{l}\text { February } \\
12\end{array}$ \\
& January, February, & December \\
14 & March, December & \\
16 & April, May, November & March, November \\
18 & June, October & \\
20 & August, September & April \\
\hline
\end{tabular}

ambient AST, when a constant approach condition is used. Typically, the minimum temperature occurs at dawn and maximum temperatures in the mid-afternoon. The time and magnitude of this diurnal variation changes throughout the year but typical values can be determined for each month. In order to quantify this aspect, each month of the year is considered to be represented by a $24 \mathrm{~h}$ day which is typical of the month. The cooling water temperature possible for each hour of this typical day has been calculated by obtaining the arithmetic average temperature for this hour, from the temperatures listed for this hour in the TRY, for this month. Thus, for example, in the developed TRY there are 31 ASTs listed for 15:00 $\mathrm{h}$ in July. This gives 31 possible cooling water temperatures, on the basis of a $3 \mathrm{~K} \mathrm{SAT}$. The average of these 31 temperatures gives the possible cooling water temperature at 15:00 $\mathrm{h}$ in the typical July day. This, then, results in a $24 \mathrm{~h}$ pattern of typical cooling water availability for each month. These graphs, which are shown for Dublin and Milan in Figs. 9-12, show the typical diurnal swing in possible average cooling water temperature, throughout the year. As the pattern is based on an average temperature it does not show the maximum and minimum

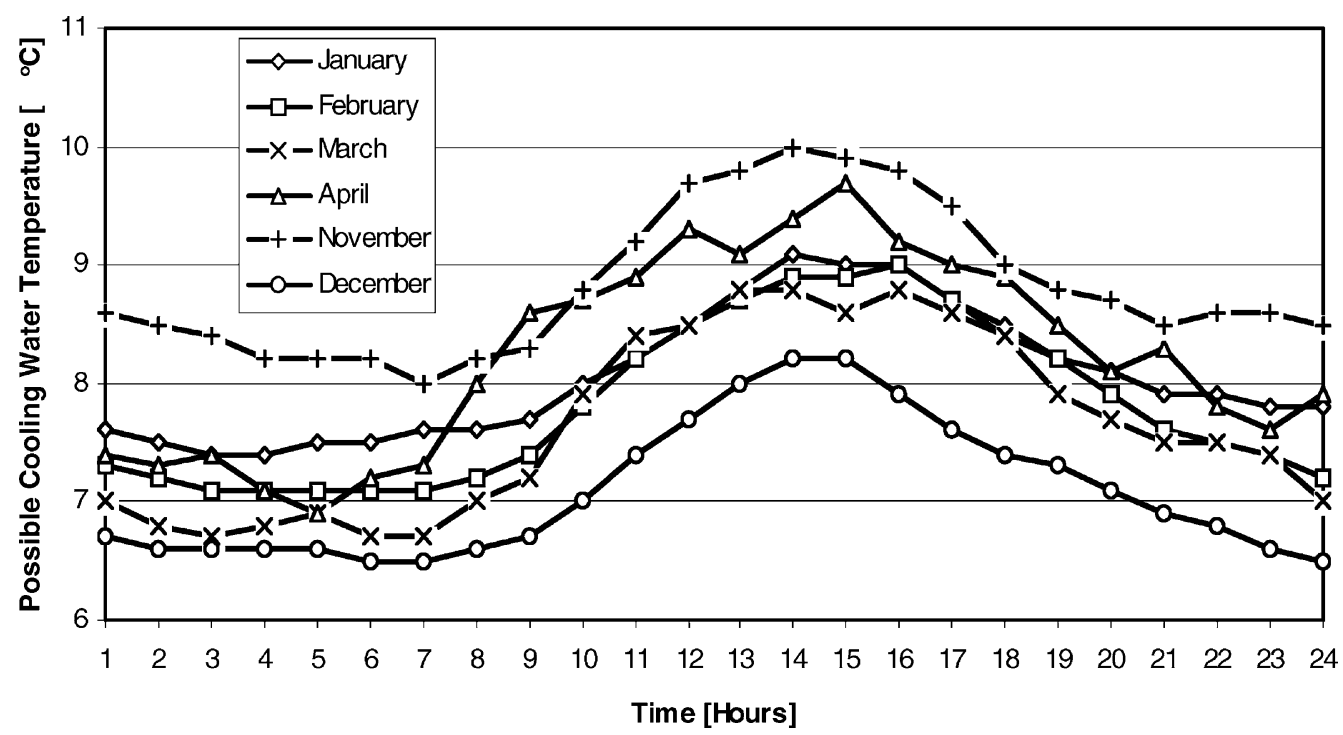

Fig. 9. Cooling water temperature possible from November to April at 3 K SAT in Dublin (based on the hourly average AST derived from the TRY data). 


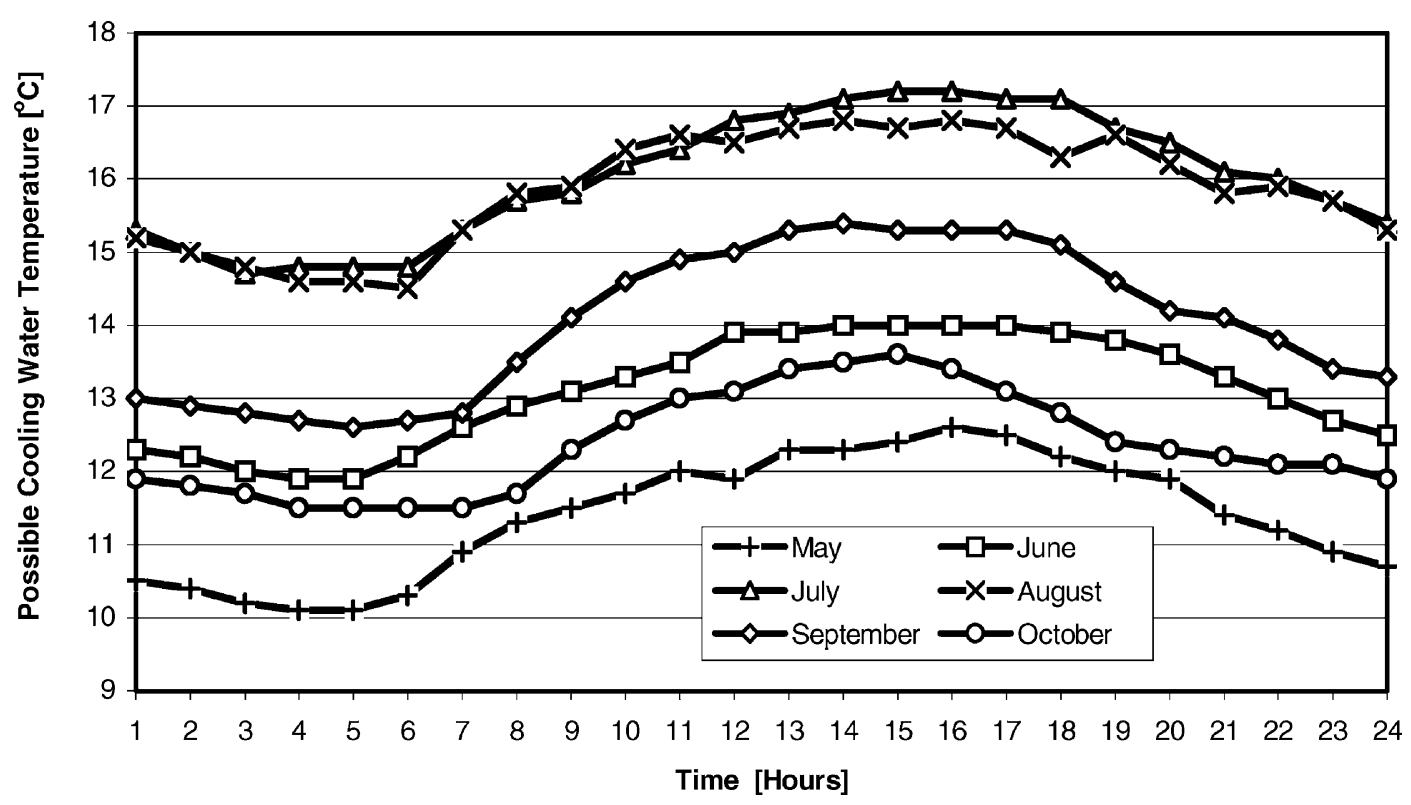

Fig. 10. Cooling water temperature possible from May to October at $3 \mathrm{~K}$ SAT in Dublin (based on the hourly average AST derived from the TRY data).

extremes, and hence is not a substitute for the availability analysis shown above. The graphs do, however, convey the typical diurnal and annual variation in the potential for cooling water generation.

Given the typical range of $2-4 \mathrm{~K}$ in the average cooling water temperature which it is possible to generate over the $24 \mathrm{~h}$ day it is useful to examine the variation in the average temperature which can be achieved with days of different length and range period. This is also of interest in view of the current trend to enhance the cooling storage capacity of buildings by extracting heat from the building fabric and contents during unoccupied periods. Figs. 13 and 14 show the variation in the average monthly cooling water temperature, which it is possible to generate with four different periods of building occupation. In the case of Dublin and Milan there is no significant difference between the average cooling water temperature of the 8-18:00 $\mathrm{h}$ day and the 8-24:00 h day throughout the year. In the months of November, December and January the average temperatures of all four day types do not differ by much more than $1 \mathrm{~K}$ for both locations. In Dublin the maximum average variation in the year, across all four day types, is $2 \mathrm{~K}$ and occurs in September. In Milan the maximum average variation is $2.8 \mathrm{~K}$ and occurs in April and May. As would be expected the lowest average cooling water temperatures are achieved with the night period (1-9:00 h), however these temperatures are generally not more than $2 \mathrm{~K}$ below the values for the day period $(8-18: 00 \mathrm{~h})$. These temperatures are, however,

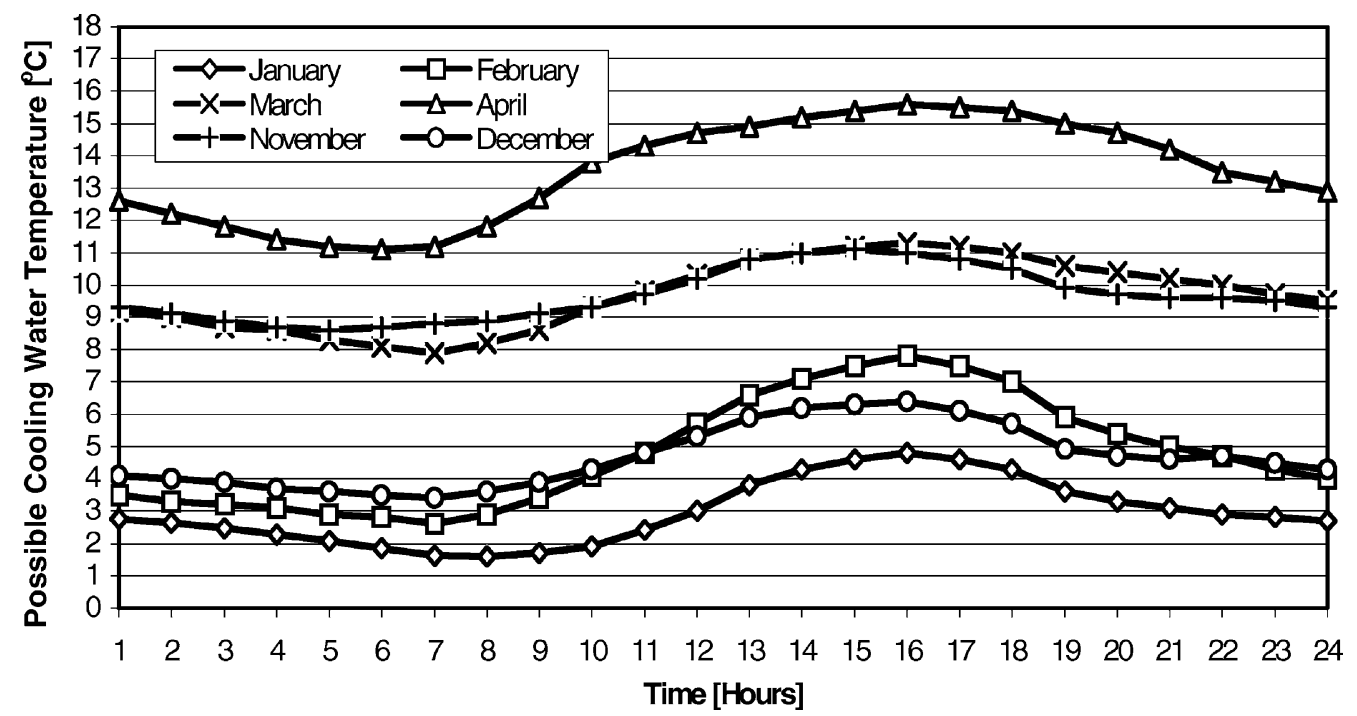

Fig. 11. Cooling water temperature possible from November to April at 3 K SAT in Milan (based on the hourly average AST derived from the TRY data). 


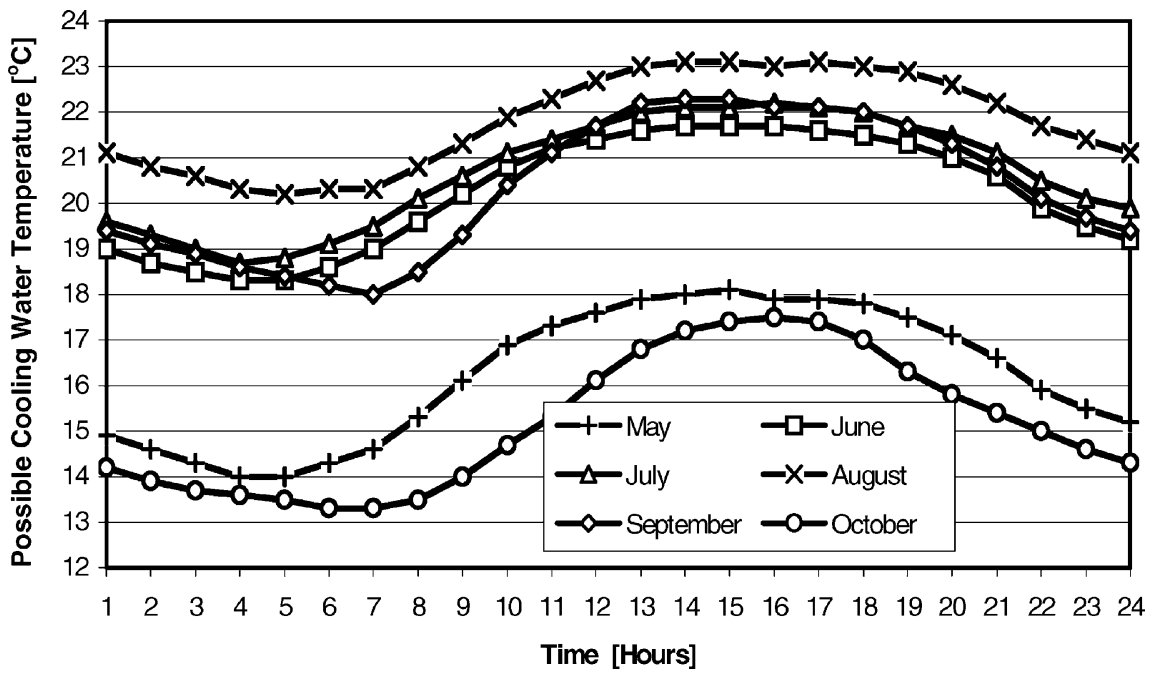

Fig. 12. Cooling water temperature possible from May to October at 3 K SAT in Milan (based on the hourly average AST derived from the TRY data).

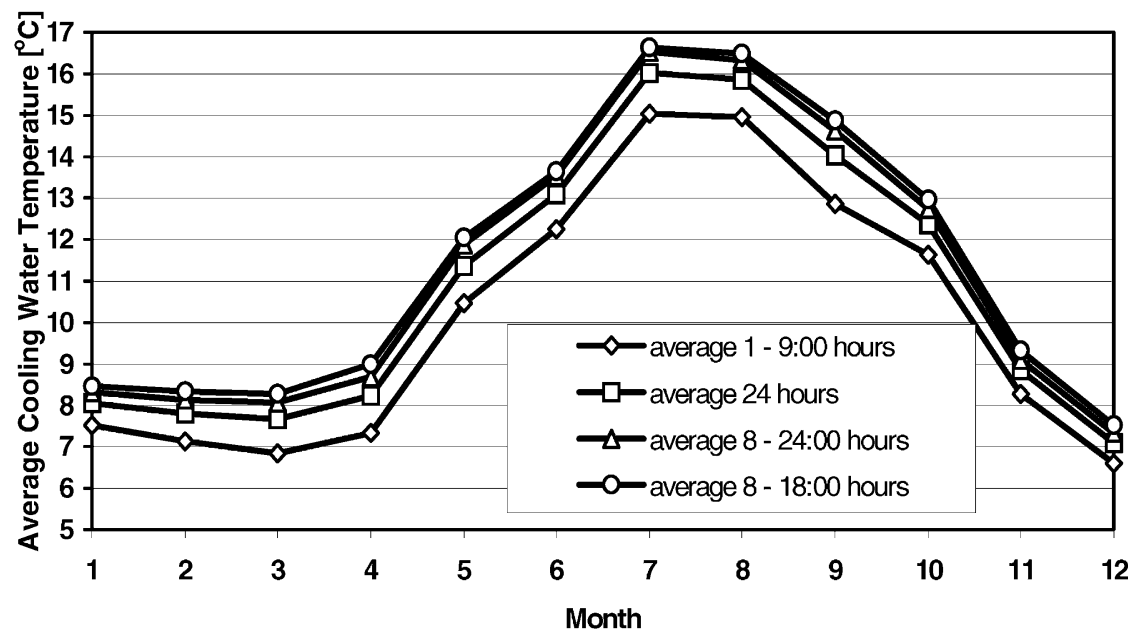

Fig. 13. Variation in average monthly cooling water temperature with length and time of cooling day for Dublin (based on $3 \mathrm{~K}$ SAT).

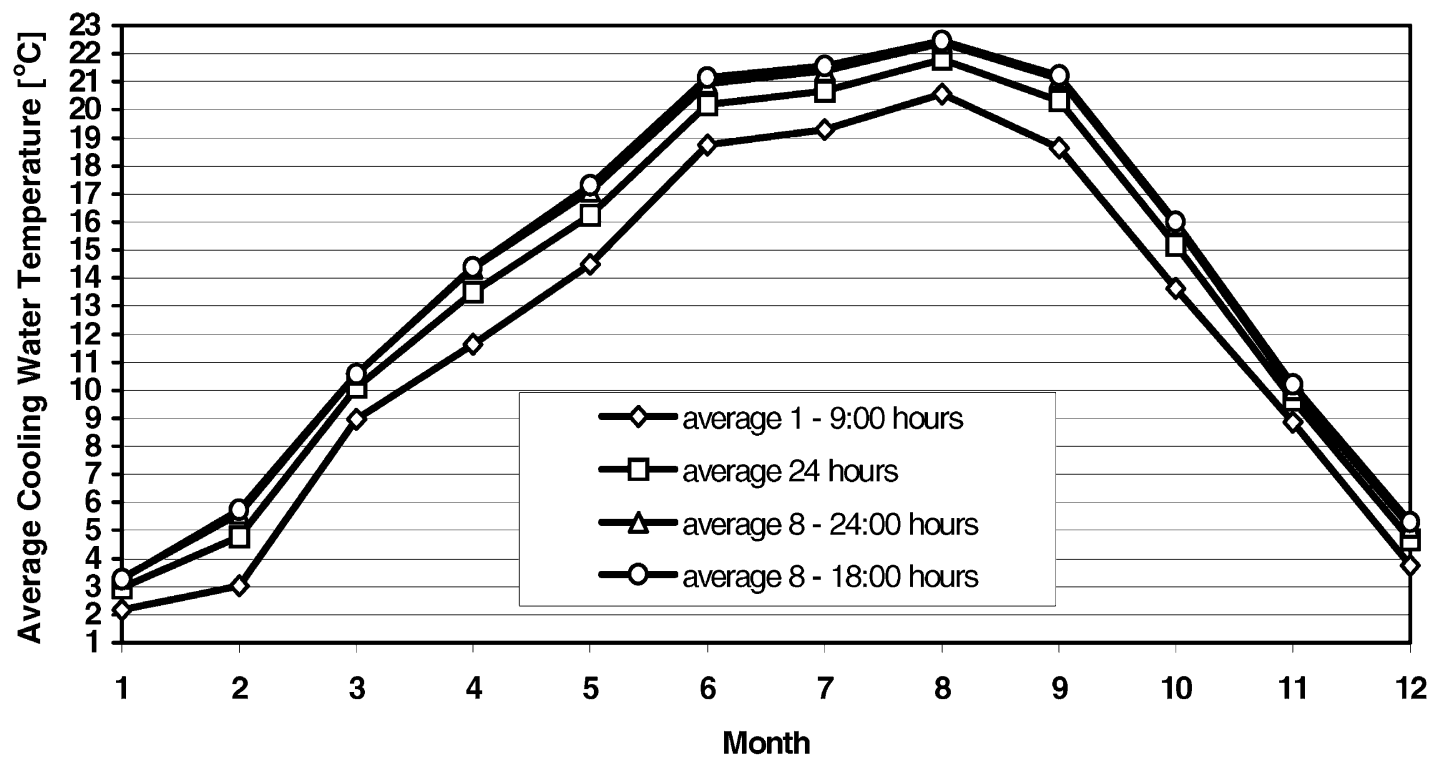

Fig. 14. Variation in average monthly cooling water temperature with length and time of cooling day for Milan (based on 3 K SAT). 


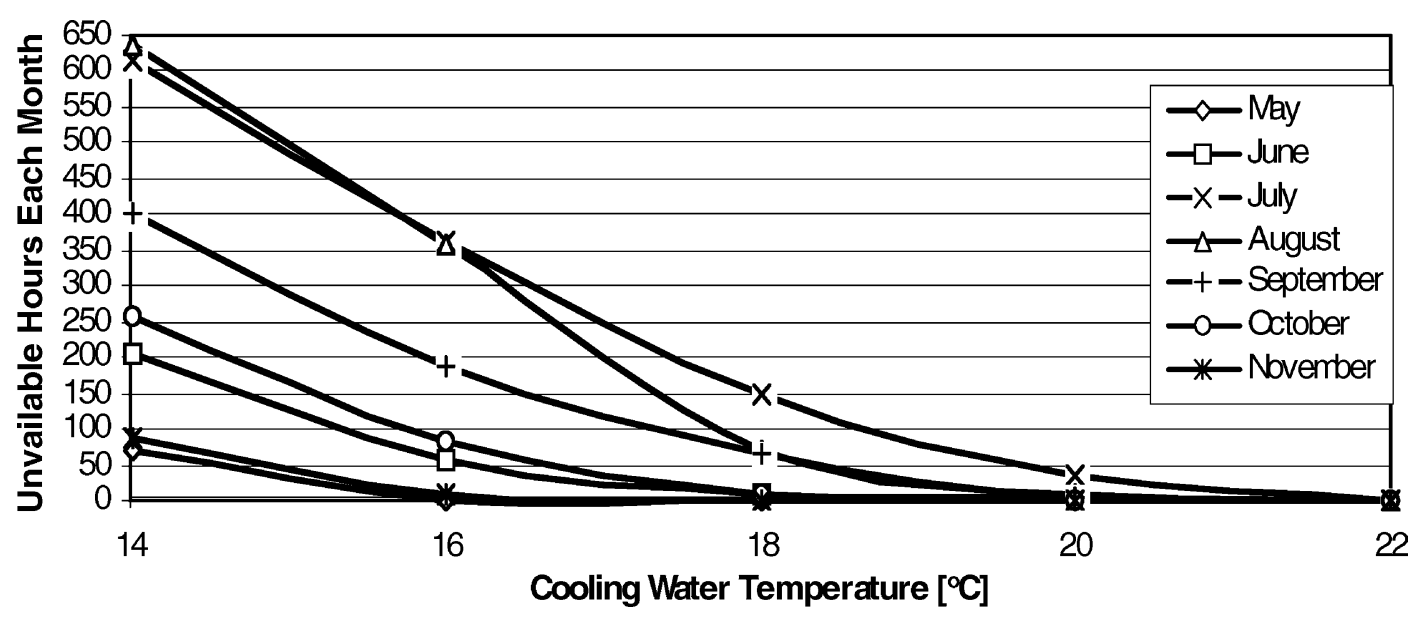

Fig. 15. Cooling water unavailability from May to October in Dublin at 3 K SAT.

the average temperatures over the periods shown. The diurnal variation, over $24 \mathrm{~h}$, in the "average for the hour" summer ambient AST is somewhat higher at 2-3 K for Dublin and 3-4 K for Milan. Hence, lower cooling water temperature can be produced at night than at midday, which can enable a degree of night-time cooling of the building fabric and contents to be achieved.

\subsection{Analysis of unavailability}

A complete assessment of annual availability requires an examination of the unavailable times in order to fully appreciate the extent of the availability. For example, a $96 \%$ availability, for a particular cooling water temperature, implies $350 \mathrm{~h}$ per annum of unavailability. This could mean 63 afternoon periods or 9 weeks, during which, the cooling water temperature cannot be generated by evaporation (however return water cooling may be possible for much of this time using load shaving techniques). Cooling is either provided by alternative means, during these periods, or thermal comfort conditions are allowed to rise, or the buildings thermal storage characteristics are such that effective damping of rising room conditions is achieved. Figs. 15 and 16 show the extent of unavailability for each month during the peak cooling months of May to October, from $14{ }^{\circ} \mathrm{C}$ cooling water temperature upwards. The importance of being able to use 16 or $18{ }^{\circ} \mathrm{C}$ cooling water in chilled ceilings, in Dublin is demonstrated, if major levels of unavailability are to be avoided in July, August and September. The difficulty of achieving any effective cooling by evaporation in June, July, August and September, in Milan is also clearly shown.

There are strong arguments in favour of the use of the indirect system, in large air-water sensible cooling systems. These centre mainly around the level of maintenance and risk of fouling associated with the direct system [11]. This has led to favouring the use of the indirect system in many contemporary applications, despite the lower annual availability levels which result. As a low SAT of $3 \mathrm{~K}$ is used in this work the availability penalty associated with the indirect system is likely to be small. Nevertheless, the quantification of this reduction, across the range of possible cooling water

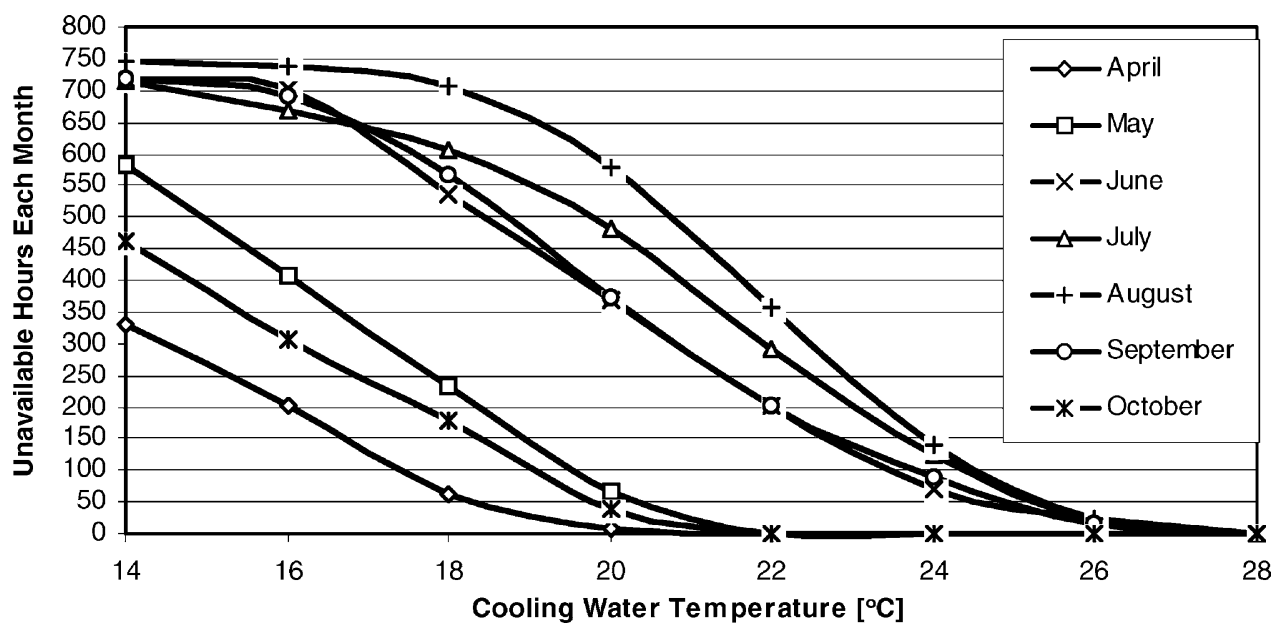

Fig. 16. Cooling water unavailability from April to October in Milan at 3 K SAT. 
Table 6

Reduction in availability introduced by the indirect system in comparison with the direct system

\begin{tabular}{|c|c|c|c|c|c|c|}
\hline $\begin{array}{l}\text { Cooling water } \\
\text { temperature }\left({ }^{\circ} \mathrm{C}\right)\end{array}$ & $\begin{array}{l}\text { Annual availability } \\
\text { Milan PAT } \\
1.5 \mathrm{~K}(\%)\end{array}$ & $\begin{array}{l}\text { Annual availability } \\
\text { Milan SAT } \\
3.0 \mathrm{~K}(\%)\end{array}$ & $\begin{array}{l}\text { Decrease in } \\
\text { percentage } \\
\text { availability for } \\
\text { indirect system Milan }\end{array}$ & $\begin{array}{l}\text { Annual } \\
\text { availability } \\
\text { Dublin PAT } \\
1.5 \mathrm{~K}(\%)\end{array}$ & $\begin{array}{l}\text { Annual } \\
\text { availability } \\
\text { Dublin SAT } \\
3.0 \mathrm{~K}(\%)\end{array}$ & $\begin{array}{l}\text { Decrease in } \\
\text { percentage } \\
\text { availability for } \\
\text { indirect system Dublin }\end{array}$ \\
\hline-8 & 0.0 & 0.0 & 0.0 & - & - & - \\
\hline-6 & 0.3 & 0.1 & 0.3 & - & - & - \\
\hline-4 & 0.7 & 0.5 & 0.2 & 0.0 & 0.0 & 0.0 \\
\hline-2 & 2.1 & 0.9 & 1.2 & 0.1 & 0.0 & 0.0 \\
\hline 0 & 5.9 & 2.9 & 3.0 & 0.4 & 0.1 & 0.3 \\
\hline 2 & 11.2 & 7.2 & 4.0 & 3.9 & 0.8 & 3.1 \\
\hline 4 & 18.2 & 12.8 & 5.4 & 11.5 & 5.6 & 5.9 \\
\hline 6 & 24.3 & 19.7 & 4.6 & 22.8 & 13.8 & 9.0 \\
\hline 8 & 30.8 & 26.0 & 4.8 & 39.3 & 26.3 & 12.9 \\
\hline 10 & 38.7 & 32.5 & 6.2 & 53.8 & 43.1 & 10.6 \\
\hline 12 & 48.1 & 40.7 & 7.4 & 69.8 & 57.7 & 12.0 \\
\hline 14 & 55.3 & 50.1 & 5.2 & 84.7 & 73.6 & 11.2 \\
\hline 16 & 64.9 & 57.3 & 7.6 & 95.1 & 87.9 & 7.1 \\
\hline 18 & 75.1 & 67.0 & 8.1 & 99.1 & 96.5 & 2.5 \\
\hline 20 & 85.9 & 78.2 & 7.6 & 99.9 & 99.4 & 0.5 \\
\hline 22 & 93.8 & 88.0 & 5.8 & 100.0 & 100.0 & 0.0 \\
\hline 24 & 98.3 & 95.2 & 3.1 & - & - & - \\
\hline 26 & 100.0 & 99.0 & 0.9 & - & - & - \\
\hline 28 & 100.0 & 100.0 & 0.0 & - & - & - \\
\hline
\end{tabular}

${ }^{a}$ PAT refers to the primary approach temperature.

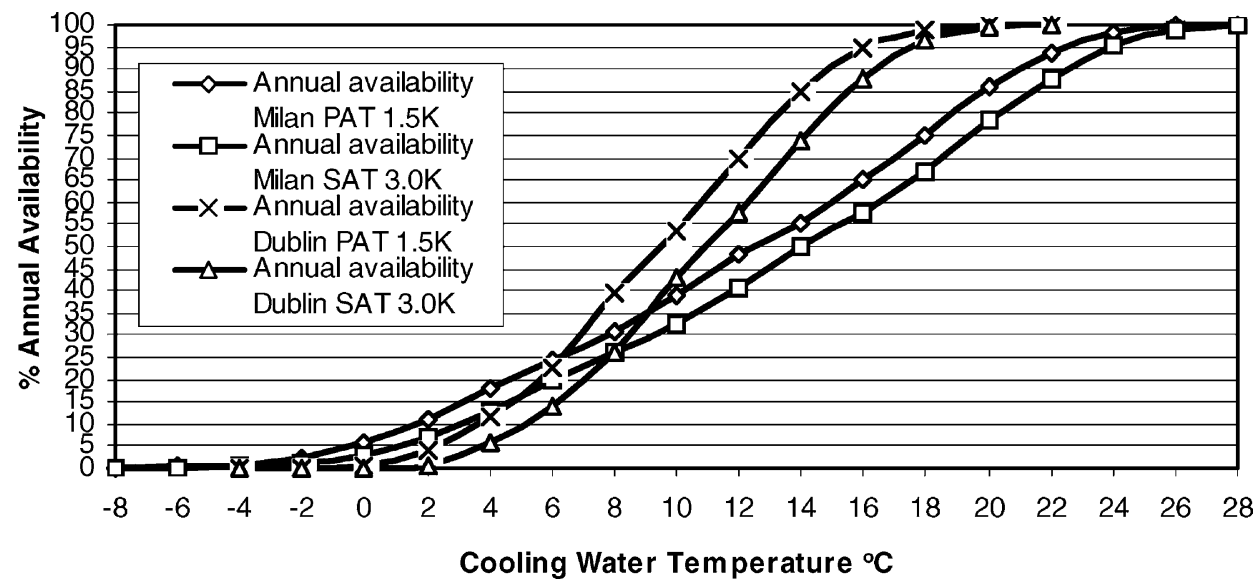

Fig. 17. Comparison of annual availability with direct and indirect system for Dublin and Milan.

temperatures, yields interesting results. Table 6 and Fig. 17 show the results of this analysis and are based on a SAT of $3 \mathrm{~K}$ and a PAT of $1.5 \mathrm{~K}$ which are generally as indicated in Table 2 for the experimental test results, at a $20 \mathrm{~kW}$ cooling load. In the case of Milan the decrease in percentage availability, for the indirect system, is small, with a maximum of $8.1 \%$ at $18{ }^{\circ} \mathrm{C}$. For Dublin the penalty is more significant rising to a maximum of $12.9 \%$ at $8{ }^{\circ} \mathrm{C}$. In Dublin the penalty is greatest between 8 and $14{ }^{\circ} \mathrm{C}$ with a diminishing level of penalty above $15^{\circ} \mathrm{C}$ in contrast with Milan, for which the level of penalty expands at this temperature. As shown in Fig. 17, in Dublin the two frequency of availability curves have the classic " $S$ " shape, separated in the centre and almost coincident at both ends. In Milan both curves are almost parallel between 4 and $22{ }^{\circ} \mathrm{C}$. The benefits of using a high cooling water temperature, in Dublin, are again evident, in Table 6. The decrease in availability introduced by the indirect system falls from $11.2 \%$ at $14{ }^{\circ} \mathrm{C}$ to $2.5 \%$ at $18{ }^{\circ} \mathrm{C}$. Hence, the case for the use of the direct system, in Dublin, is weak at the higher cooling water temperatures of $16-18{ }^{\circ} \mathrm{C}$, which are used in chilled ceilings.

\section{Discussion of results}

In general the results show an extensive potential for cooling water generation by evaporative means, in the case 
Table 7

Percentage annual cooling availability for two sensible cooling system ( $24 \mathrm{~h}$ basis)

\begin{tabular}{|c|c|c|c|}
\hline Sensible cooling system & $\begin{array}{l}\text { Design secondary } \\
\text { cooling water temperature }\left({ }^{\circ} \mathrm{C}\right)\end{array}$ & $\begin{array}{l}\text { Dublin cooling availability } \\
\text { at } 3 \mathrm{~K} \mathrm{SAT}(\%)\end{array}$ & $\begin{array}{l}\text { Milan cooling availability } \\
\text { at } 3 \mathrm{~K} \mathrm{SAT}(\%)\end{array}$ \\
\hline \multirow[t]{3}{*}{ Dry mode fan coil units } & 10 & 43.1 & 32.5 \\
\hline & 12 & 57.7 & 40.7 \\
\hline & 14 & 73.8 & 50.1 \\
\hline \multirow[t]{7}{*}{ Chilled ceiling panels and beams } & 14 & 73.8 & 50.1 \\
\hline & 15 & 81.5 & 53.3 \\
\hline & 16 & 88.0 & 57.3 \\
\hline & 17 & 93.2 & 62.5 \\
\hline & 18 & 96.7 & 67.0 \\
\hline & 19 & 98.4 & 72.2 \\
\hline & 20 & 99.4 & 78.2 \\
\hline
\end{tabular}

of Dublin and a less extensive but significant potential in the case of Milan. The assessment of this potential for individual projects clearly depends on the yearly and daily pattern of the cooling load, the balance between the internal and external loads, the length of the cooling season and on the maximum secondary cooling water temperature for which the cooling system has been designed. Table 7 shows the maximum percentage cooling annual availability, on a $24 \mathrm{~h}$ day basis, for two types of sensible cooling system. Clearly use of a high cooling water temperature, with chilled ceilings, offers major potential for sensible cooling of buildings. Whether this form of cooling can supplant rather than simply supplement the refrigeration system depends on the development of chilled ceilings which have effective cooling outputs at higher cooling water temperatures. Convection chilled beams have been developed with effective outputs at $18{ }^{\circ} \mathrm{C}$ [16]. Some recent work on the development of radiant cooling panels is also encouraging in this respect, in particular increasing the convection component of the cooling output.

Roulet et al. [21] describes the manufacture and performance of large stainless steel panels for radiant cooling of buildings. The design of the panel departs from the conventional coiled tube, rear mounted on a perforated metal plate, and uses a rectangular waterway, formed between two flat stamped plates, in a manner similar to, but lighter than, conventional pressed metal heating radiators. The result of this design is that heat transfer resistance between the cooling medium and the panel surface is reduced, contact area is increased and more uniform surface temperatures are achieved. Roulet et al. suggest that when insulation is not placed on the upper side of the panel the air in the ceiling void can also contribute to convection cooling, if it is allowed to circulate to the room. Panels do not necessarily have to be placed to form a continuous flat surface but can be used to form cooling fins, profiles, ducts, or separated panels. Hence, panel surface area can be increased. The paper suggests that the cooling output of such panels arranged in this way is probably closer to $100 \mathrm{~W} / \mathrm{m}^{2}$ at $8{ }^{\circ} \mathrm{C}$ panel surface to room air temperature difference.
Conventional panels would have an output, under these conditions of approximately $75 \mathrm{~W} / \mathrm{m}^{2}$. More recent work by Owen and King [20] also suggests the possibility of raising the cooling output of radiant panels.

On the basis of the CIBSE research report finding [6] that $18^{\circ} \mathrm{C}$ chilled water can, if cooling loads and panel design are suitable, be successfully used in panels and beams, the maximum annual availability is at least $96 \%$ in Dublin and $67 \%$ in Milan. As chilled ceiling panels and beams usually operate with a $2-3 \mathrm{~K}$ temperature difference between flow and return, the cooling tower can contribute to return water cooling on those occasions when it is unable to produce a supply water temperature of $18{ }^{\circ} \mathrm{C}$, a technique known as load shaving [11]. If, for example, a cooling water temperature of $16{ }^{\circ} \mathrm{C}$ is sought at a time when the ambient AST is $14{ }^{\circ} \mathrm{C}$ this is not possible with a design based on a $3 \mathrm{~K}$ SAT. However, it is possible to cool the return water from 19 to $17{ }^{\circ} \mathrm{C}$ in the tower and subsequently to $16^{\circ} \mathrm{C}$ by means of the refrigeration system. This increases the availability of the tower for partial cooling of the load from 88 to $93.2 \%$ for Dublin and from 57.3 to $62.5 \%$ for Milan. In fact for Dublin, the load shaving technique can always $(99.4 \%$ of the year) contribute to the production of cooling water at $18{ }^{\circ} \mathrm{C}$, when the return water temperature is $21^{\circ} \mathrm{C}$ or less. For Milan the technique can contribute to $18{ }^{\circ} \mathrm{C}$ cooling up to an ambient AST of $17{ }^{\circ} \mathrm{C}$ which implies approximately $80 \%$ annual availability for full or partial cooling. This is significant as it implies, with reference to Fig. 12 that the tower can contribute to cooling at night from 22:00 to 8:00 h during the months of June, July and September.

The diurnal variation in the average summer ambient AST is $2-3 \mathrm{~K}$ for Dublin and $3-4 \mathrm{~K}$ for Milan. Hence, lower cooling water temperature can be produced at night than at midday, which can enable night-time cooling of the building fabric and contents to be achieved. The fall in cooling system capacity during the day by the inability of the tower to maintain a cooling water set point is offset by the increased cooling storage provided by night-time cooling. Hence, the day-time rise in room thermal conditions is damped. Further research is, however, required on this 
aspect in order to determine the room comfort conditions which results. However, the radiant cooling produced by the chilled ceiling panel, is particularly suited to this arrangement as it is inherently a slow response system having a high degree of self regulation as demonstrated by Butler [5].

As the maximum secondary cooling water temperature is $18{ }^{\circ} \mathrm{C}$, cooling tower primary water will generally not exceed $20{ }^{\circ} \mathrm{C}$ when operating in summer. Hence, the possibilities for the growth of legionella are minimal compared with conventional refrigeration condenser water cooling towers in which water temperatures are normally in the higher growth range of $27-33^{\circ} \mathrm{C}$. Thirty-seven degree Celsius being the optimum temperature for growth of the bacterium [7]. This fact is important in promoting greater confidence in the use of cooling towers for evaporative cooling, particularly in commercial buildings.

\section{Conclusions}

The results of a detailed meteorological analysis of evaporative cooling availability for a northern and southern European city, Dublin and Milan, have been presented and discussed. Dublin is at the lower end and Milan is at the upper end of the range of European locations with temperate climates. Hence, most locations with a north-west European temperate climate would be likely to return an evaporative cooling performance between these two limits. The results confirm a major potential for the generation of cooling water, which can be used to provide effective cooling of modern buildings by means of contemporary water based sensible cooling systems, such as fan coils and chilled ceiling panels and beams. While the technique offers most potential in locations with a northern European temperate climate it has a significant potential to contribute to cooling in southern European cities during the non-summer months and also at other times by means of load shaving (return water cooling). In order to take maximum advantage of the technique the building needs to be designed to minimise solar and external heat gain and to separate the latent and sensible cooling functions. The technique is particularly suited to large deep plan buildings with stable and internally dominated sensible load patterns and hence long cooling seasons.

The following specific conclusions can be drawn:

1. The AST determined from the meteorological TRY is a suitable means of assessing evaporative cooling potential and gives very similar results to an analysis based on a record of wet bulb occurrence.

2. The SAT has a major impact on the percentage availability at all cooling water temperatures in both locations and when minimised to $3 \mathrm{~K}$ provides high levels of annual availability, with an availability level of $50 \%$ in Milan and $74 \%$ in Dublin at a secondary cooling water temperature of $14{ }^{\circ} \mathrm{C}$.
3. The potential is heavily dependent the design secondary cooling water temperature and is greatest in buildings which have been designed to operate with the high secondary cooling water temperatures of $16-18{ }^{\circ} \mathrm{C}$ and which incorporate load shaving. Cooling water can be generated at $18{ }^{\circ} \mathrm{C}$, for chilled ceiling panels and beams, for $97 \%$ of the year in Dublin and for $67 \%$ of the year in Milan during the months of October-May. During the months of June, July and September in Milan there is also some potential for night-time load shaving.

4. Dry mode fan coil units designed to operate with $14{ }^{\circ} \mathrm{C}$ cooling water can be supplied from November to May in Dublin and from November to March in Milan.

5. In Dublin $16{ }^{\circ} \mathrm{C}$ cooling water is available from October to May, which implies that buildings, such as educational institutes which are lightly occupied during July, August and September may be successfully sensibly cooled throughout the year, without the use of refrigeration cooling, if they are designed to operate with $16{ }^{\circ} \mathrm{C}$ cooling water. Such buildings, often incorporate displacement ventilation systems, supplying air at 18 or $19{ }^{\circ} \mathrm{C}$ to the space, which can be achieved by evaporative cooling from October to May.

The diurnal variation in the average summer ambient AST is 2-3 K for Dublin and 3-4 K for Milan. Hence, somewhat lower cooling water temperature can be produced at night than at midday, which can enable night-time cooling of the building fabric and contents to be achieved. These relatively small diurnal variations reflect the fact that the change in the ambient enthalpy of the air between day and night is less than the change in ambient dry bulb temperature resulting in relatively flat $24 \mathrm{~h}$ patterns of cooling water temperature.

6. The penalty of diminished cooling availability associated with the indirect system for a $3 \mathrm{~K} \mathrm{SAT} \mathrm{is} \mathrm{small} \mathrm{in}$ the case of Milan with a maximum of $8.1 \%$ and relatively small in Dublin, with a maximum of $12.9 \%$.

7. This paper presents an analysis of two European TRYs. Many other data bases are available for European locations for which a similar analysis is required to develop the knowledge of the potential of this alternative form of cooling in the European context.

\section{Acknowledgements}

This research programme has been supported by a research grant from the CIBSE (Republic of Ireland Branch) research fund, by an applied research grant from Enterprise Ireland, and by the Dublin Institute of Technology (DIT), Faculty of Engineering, research seed fund. Equipment and services, donated by many private companies and individuals, is gratefully acknowledged. The support of the Buildings Office, DIT and of the laboratory staff of the Department of Building Services Engineering is also acknowledged. 
Appendix A

See Tables A.1 and A.2, Fig. 18.

Table A.1

Extract from meteorological test reference year for Dublin

\begin{tabular}{lllllllllllll}
\hline A & B & C & D & E & F & G & H & I & K & L & M & N \\
\hline Station & Time & DBT $(\times 10)$ & Global & Diffuse & Direct & Sunshine & Relative & Wind & Year & Month & Day & Hour \\
\hline $\begin{array}{l}\text { Dublin } \\
\text { airport }\end{array}$ & GMT & Celsius & $\begin{array}{l}\text { Radiation } \\
\left(\mathrm{J} / \mathrm{cm}^{2}\right)\end{array}$ & $\begin{array}{l}\text { Radiation } \\
\left(\mathrm{J} / \mathrm{cm}^{2}\right)\end{array}$ & $\begin{array}{l}\text { Radiation } \\
\left(\mathrm{J} / \mathrm{cm}^{2}\right)\end{array}$ & $\begin{array}{l}\text { Duration } \\
(\mathrm{min})\end{array}$ & $\begin{array}{l}\text { Humidity } \\
(\%)\end{array}$ & $\begin{array}{l}\text { Speed } \\
(\times 10 \mathrm{~m} / \mathrm{s})\end{array}$ & $\begin{array}{l}\text { based } \\
\text { on }\end{array}$ & & \\
\hline DUB & $\mathrm{T}$ & 178 & 128 & 105 & 31 & 48 & 73 & 36 & 79 & 7 & 4 & 10 \\
DUB & $\mathrm{T}$ & 188 & 172 & 139 & 41 & 48 & 66 & 31 & 79 & 7 & 4 \\
DUB & $\mathrm{T}$ & 192 & 205 & 135 & 82 & 36 & 64 & 21 & 79 & 7 & 4 & 12 \\
\hline
\end{tabular}

Table A.2

Extract from new psychrometric test reference year developed for Dublin

\begin{tabular}{lcccccccccccc}
\hline $\begin{array}{l}\text { Year } \\
\text { based on }\end{array}$ & Month & Day & Hour & DBT $\left({ }^{\circ} \mathrm{C}\right)$ & $\begin{array}{l}\text { Relative } \\
\text { humidity } \\
(\%)\end{array}$ & $\begin{array}{l}\text { Saturation } \\
\text { vapour } \\
\text { pressure }(\mathrm{Pa})\end{array}$ & $\begin{array}{l}\text { Vapour } \\
\text { pressure } \\
(\mathrm{Pa})\end{array}$ & $\begin{array}{l}\text { Humidity } \\
\text { ratio } \\
(\mathrm{g} / \mathrm{kg})\end{array}$ & $\begin{array}{l}\text { Specific } \\
\text { volume } \\
\left(\mathrm{m}^{3} / \mathrm{kg}\right)\end{array}$ & $\begin{array}{l}\text { Density } \\
\left(\mathrm{kg} / \mathrm{m}^{3}\right)\end{array}$ & $\begin{array}{l}\text { Enthalpy } \\
(\mathrm{kJ} / \mathrm{kg})\end{array}$ & $\begin{array}{l}\text { Adiabatic } \\
\text { saturation } \\
\text { temperature }\left({ }^{\circ} \mathrm{C}\right)\end{array}$ \\
\hline 69 & 1 & 1 & 1 & 2.2 & 100 & 716 & 716 & 4.46 & 0.7867 & 1.28 & 13.26 & 2.2 \\
69 & 1 & 1 & 2 & 2.7 & 98 & 742 & 727 & 4.53 & 0.7881 & 1.27 & 13.94 & 2.6 \\
74 & 5 & 31 & 11 & 14.8 & 63 & 1682 & 1060 & 6.63 & 0.8227 & 1.22 & 31.44 & 11.0 \\
74 & 5 & 31 & 12 & 12.9 & 71 & 1487 & 1056 & 6.61 & 0.8173 & 1.23 & 29.44 & 10.1 \\
70 & 10 & 21 & 18 & 8.2 & 75 & 1087 & 815 & 5.09 & 0.8039 & 1.25 & 20.89 & 6.2 \\
70 & 10 & 21 & 19 & 7.9 & 78 & 1065 & 831 & 5.19 & 0.8030 & 1.25 & 20.83 & 6.1 \\
\hline
\end{tabular}

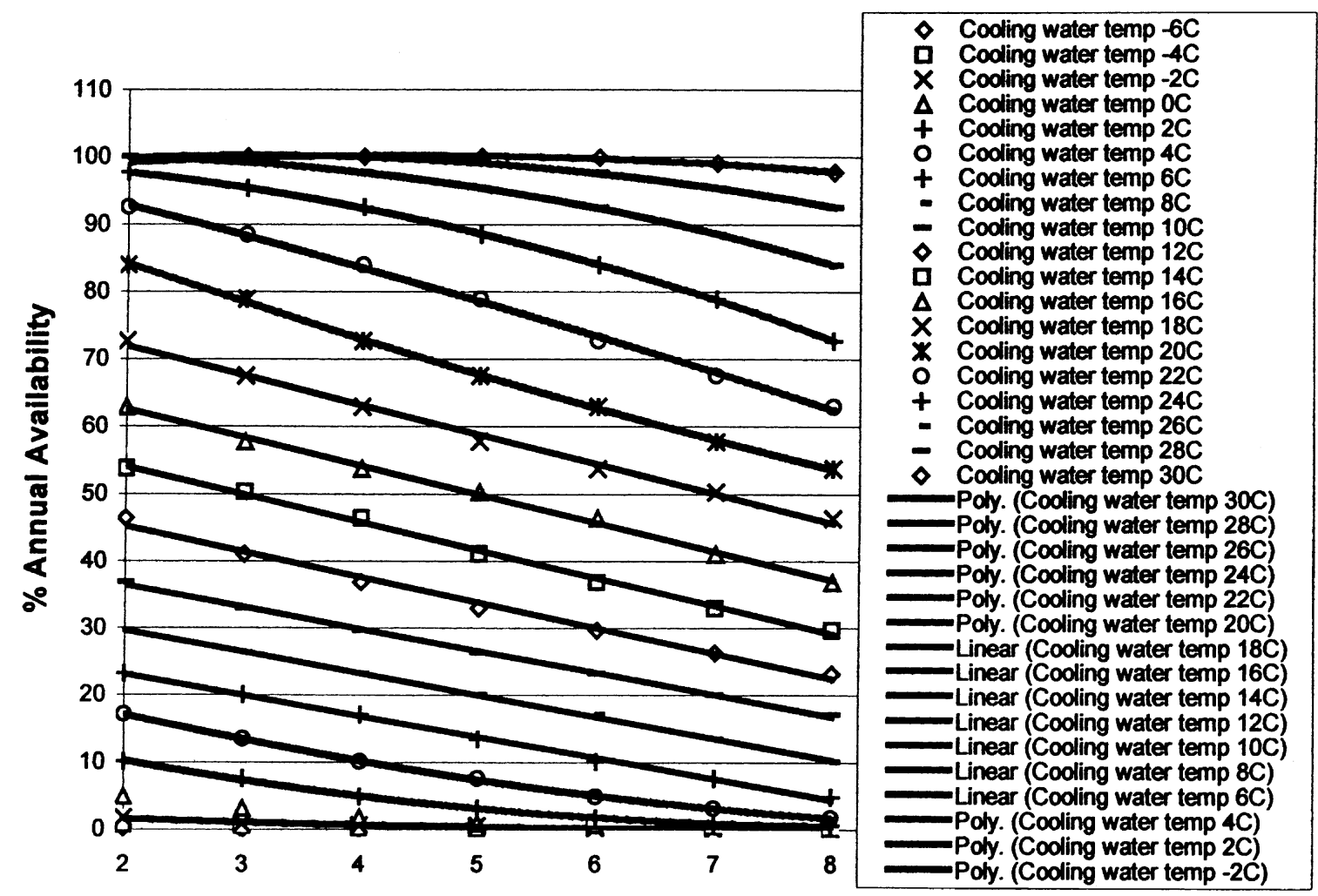

Secondary Approach Temperature [K]

Fig. 18. Impact of secondary approach temperature on percentage annual availability of cooling water in Milan for the full range of possible cooling water temperatures. 


\section{References}

[1] Asea Brown Boveri Flakt (ABB), Fan coil technical manual (Aerovent Classic), BEFLA/9401/ENG/A, ABB Doortstraat 4, Belgium, 1994.

[2] ASHRAE, Fundamentals Handbook, ASHRAE, Atlanta, GA, 1997.

[3] ASHRAE, HVAC Systems and Equipment Handbook, ASHRAE, Atlanta, GA, 1996.

[4] ASHRAE, Applications Handbook, ASHRAE, Atlanta, GA, 1995.

[5] D.J.G. Butler, Chilled ceilings: a free cooling opportunity, in: Proceedings of CIBSE National Conference 1998, Bournemouth, UK, 1998, pp. 273-279.

[6] CIBSE, Chilled ceilings and beams, research report RR5, CIBSE, London, 1998.

[7] CIBSE, Minimising the Risk of Legionnaires' Disease Technical Memorandum 13, CIBSE, London, 1991.

[8] CIBSE, CIBSE Guide, vol. A, CIBSE, London, 1986.

[9] B. Costelloe, D. Finn, 2001. Energy reduction by enhanced evaporative cooling of buildings in maritime climates, in: Proceedings of the Solar Energy Society Biennial Conference, Belfast, September 2001, pp. 262-269.

[10] B. Costelloe, D. Finn, 2000. The design and performance of an evaporative cooling test rig for a maritime climate, in: Proceedings of Joint CIBSE/ASHRAE Conference, Dublin, September 2000, pp. $830-845$.
[11] T. De Saulles, Free cooling system-design and application guidance. BSRIA, Bracknell, UK, 1996.

[12] J. Facao, A.C. Oliveira, Thermal behaviour of closed wet cooling towers for use with chilled ceilings, Applied Thermal Engineering 20 (2000) 1225-1236.

[13] J. Field, Building analysis. 1. City Square Leeds, Building Services Journal, 12 (1998) 14-18.

[14] G. Gan, S.B. Riffat, L. Shao, Performance prediction of a prototype closed wet cooling tower, Journal of the Institute of Energy 73 (495) (2000) 106-113.

[15] H. Goshayshi, J.F. Missenden, R. Tozer, G.G. Maidment, 2000. Improving cooling tower performance for sustainable refrigeration, in: Proceedings of Joint CIBSE/ASHRAE Conference, Dublin, September 2000, pp. 344-350.

[16] Halton, Technical performance data (Halton, CD-ROM), Halton OY, 01510 Vantaa, Finland, 1997.

[17] W.P. Jones, Air Conditioning Applications and Design, Arnold, London, 1997.

[18] T.H. Kuehn, J.W. Ramsey, J.L. Threlkeld, Thermal Environmental Engineering, Prentice-Hall, Englewood Cliffs, NJ, 1998.

[19] D. Murphy, Cooling towers for free cooling, ASHRAE Journal (June) (1991) 16-26.

[20] G. Owen, G. King, High capacity chilled ceilings, Building Services Journal 3 (March) (2001) 47.

[21] C.A. Roulet, J.P. Rossy, Y. Roulet, Using large radiant panels for indoor climate conditioning, Energy and Buildings 30 (1999) 121-126. 